\title{
Factors contributing to rising cesarean section rates in South Asian countries: A systematic review
}

\author{
Sulochana Dhakal-Rai', Edwin van Teijlingen², Pramod R. Regmi ${ }^{3}$, Juliet Wood ${ }^{4}$, \\ Ganesh Danga| ${ }^{5,6}$, Keshar Bahadur Dhakal ${ }^{7}$ \\ ${ }^{1}$ PhD Student, Bournemouth University, UK, ${ }^{2}$ Professor, Department of Midwifery \& Health Sciences, Bournemouth \\ University, ${ }^{3}$ Senior Lecturer in International Health, Department of Nursing Science, Faculty of Health and Social \\ Sciences, Bournemouth University, ${ }^{4}$ Senior Lecturer in Midwifery, Department of Midwifery \& Health Sciences, Faculty \\ of Health and Social Sciences, Bournemouth University, ${ }^{5}$ Professor, Department of Obstetrics and Gynaecology, \\ Kathmandu Model Hospital, ${ }^{6}$ Visiting Professor, Department of Obstetrics and Gynaecology, Bournemouth University, \\ United Kingdom, ${ }^{7}$ Chief Consultant, Department of Obstetrics and Gynaecology, Karnali Province Hospital, Surkhet, \\ Professor, Karnali Academy of Health Sciences, Nepal
}

\section{A B S T R A C T}

Rising cesarean section (CS) rates are a global public health problem. The systematic review investigates key indications for performing CS and factors significantly associated with the rising rate of CS in South Asia. Primary studies in South Asia published between January 2010 and December 2018 were searched using relevant electronic databases: MEDLINE, Scopus, PubMed, Web of Science, CINAHL, NepJOL, and BanglaJOL. A narrative synthesis of the indications for performing $C S$ and factors significantly associated with the rising $C S$ rates was performed using content analysis. A total of 68 studies were included in this review. The most common medical indication for CS was fetal distress, followed by previous CS, antepartum hemorrhage (including placenta previa/abruption), cephalopelvic disproportion, failed induction, hypertensive disorders in pregnancy, oligohydramnios, and non-progress of labor. Maternal request was the most common non-medical indication for conducting CS. Higher maternal age was the most common significant factor associated with the rising CS rate followed by higher maternal education, urban residency, higher economic status, previous CS, pregnancy/childbirth complications, and lower parity/nulliparity. Preference for $\mathrm{CS}$ and increasing private number hospital were also factors contributing to the rising rate. Several key indicators and factors significantly associated with rising CS rate are revealed. These key indicators and significant factors reflect the global trend. Reduction in the use of primary CS, unless medically warranted, would help stem rates of CS. Realistic and candid explanation to pregnant women and their families regarding the benefits of vaginal birth for women and babies should form an integral part of maternity care as these are issues of public health.

\section{Access this article online}

Website:

http://nepjol.info/index.php/AJMS DOI: $10.3126 / a j m s . v 13 i 2.40904$

E-ISSN: 2091-0576

P-ISSN: 2467-9100

Copyright (c) 2022 Asian Journal of Medical Sciences

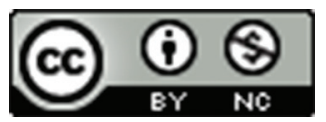

This work is licensed under a Creative Commons Attribution-NonCommercial 4.0 International License.

Key words: Cesarean section; Indication; South Asia; Systematic review

\section{INTRODUCTION}

The rising rate of cesarean section (CS) is a global public health problem. The World Health Organization (WHO) recommended CS rates of $10-15 \%{ }^{1}$ A CS rate $>10 \%$ at the population level does not reduce maternal and new-born mortality rates. ${ }^{2}$ Globally, the CS rate nearly doubled between 2000 (12.1\%) and 2015 (21.1\%). ${ }^{3}$ In the light of this, there is an emphasis on the optimum use of CS for medically indicated reasons to avoid unnecessary interventions in low-risk pregnancies. ${ }^{4,5}$ However, it is apparent that CS is often performed without medical

Address for Correspondence:

Sulochana Dhakal-Rai, Department of Midwifery and Health Sciences, Faculty of Health and Social Sciences, Bournemouth University, Bournemouth Gateway Building, St. Paul's Lane, Bournemouth, BH8 8GP, United Kingdom. Phone: +44 1202 973122,

E-mail: sdhakalrai@bournemouth.ac.uk 
indication, and this is associated with an increased risk of severe maternal outcomes. ${ }^{6} \mathrm{CS}$ is associated with many short and long-term maternal and infant health problems and can also adversely affect subsequent pregnancies. ${ }^{7}$ The risk of serious maternal morbidity rises with each repeat CS. ${ }^{8}$ In addition, unnecessary CS is costly for families and health systems. ${ }^{9}$ Thus, CS should only be performed when medically necessary and where its benefits compensate for the associated costs and risks. ${ }^{10}$

In the South Asia, the CS rate almost tripled between $2000(7.2 \%)$ and $2015(18.1 \%),{ }^{3}$ and the highest CS rates are in cities. ${ }^{11}$ In Bangladesh, CS rates increased over fivefold from $2004(3.5 \%)$ to 2014 (23\%). ${ }^{12}$ A higher prevalence of CS was reported in urban areas $(62.88 \%) .{ }^{13}$ In India, the estimated overall CS rate 2010-2016 was $17.2^{\%} \%^{14}$ with high CS rates reported in urban $(27.20 \%)^{13}$ and in private health facilities $(29.5 \%) .{ }^{15}$ Furthermore, the disparity in CS rate between private and public hospitals has increased over the years in India. ${ }^{16}$ In Nepal, the overall CS rate is $12.21 \%,{ }^{13}$ but the CS rates are rising in urban areas. ${ }^{17}$ CS rates in private hospitals increased three-fold from $1996(8.9 \%)$ to $2016(26.3 \%) \cdot{ }^{18}$ In Pakistan, the overall CS rate increased about five-fold from 1991-1992 (2.7\%) to 2012-2013 (15.8\%) and higher in urban (27.79\%). ${ }^{19}$ In Sri Lanka, a study reported an increased CS rates (from 29.6\% in 2008 to $33.6 \%$ in 2010). ${ }^{20}$ Similarly, in the Maldives, the CS rate is reported to be high in urban areas (30.18\%). ${ }^{13}$ The utilization of CS is still low (3.4\%) in Afghanistan. ${ }^{21}$ A hospital-based study showed that the CS rate was 18.7\% in Bhutan. ${ }^{22}$ The rising rates of CS in South Asia raise questions about performing CS for unnecessary reasons. A study conducted in Nepal also revealed that CSs are performed for suboptimal indications in relation to fetal distress and prolonged labor, because fetal heart rate monitoring was poor for the diagnosis of fetal distress and use of partograph was also poor to diagnose prolong labor proceeding the decision for the emergency $\mathrm{CSs}^{23}$ Hence, there is a need to explore the key indications and factors underlying the rising CS rates not only to address the CS rate itself but also to avoid over medicalization of childbirth in South Asia. By considering the range of key indications for CS, and factors associated with, rising CS in South Asian countries, this systematic review aims to answer the question: What are the factors contributing to the rising CS rates in South Asian countries?

\section{Aims and objectives}

Aim: To assess factors contributing to rising cesarean section rates in South Asian countries.

Objectives: To investigates key indications for performing CS and factors significantly associated with the rising rate of CS in South Asia.

\section{MATERIALS AND METHODS}

This systematic review included studies according to the protocol registered in PROSPERO in 2019 (ID: CRD42019131237).

\section{Inclusion and exclusion criteria}

Primary quantitative cross-sectional and cohort studies which focussed on the indications/factors/determinants for CS from 2010 to 2018 in South Asia and written in English were included in this review. For mixed-methods studies, only quantitative data were included. In addition, studies accessible online database until 30 May 2019 were included. All case control studies, interventional studies, studies using only secondary data and studies with critical appraisal skills program (CASP) scoring $<20$ were excluded.

\section{Search strategy}

The systematic review used the following electronic databases: MEDLINE, Scopus, PubMed, Web of Science, CINAHL, NepJOL, and BanglaJOL. Databases were searched for articles published from $1^{\text {st }}$ January 2010 to $30^{\text {th }}$ December 2018 reporting factors, reasons, causes, determinants, and indications for CS. Medical subject headings terms and key words for "cesarean;" "cesarean," "C-section," were combined with countries (Nepal, India, Pakistan, Bangladesh, Afghanistan, Sri Lanka, Maldives, Bhutan) using Boolean operators. Titles and abstracts were screened for the reasons, factors, indications and determinants of CS. The search strategy also included hand searching of journals and reference lists of included articles. Key articles cited by multiple authors were checked on Google Scholar, and authors of relevant published protocols were contacted if necessary (Supplementary Table 1).

\section{Data extraction and study outcome}

All extracted articles were assessed for inclusion eligibility by the first author (SD). Titles and abstracts comprising factors/causes/indications/reasons for CS were included, after which the full text of each article was considered. The data extraction form was developed by the research team. Data extraction included: Author, Published Year, Country/Setting, Study design/method, Study population/ Sample size, Key findings (Supplementary Tables 2 and 3). Extracted data were checked for accuracy by other authors (EvT, JW, PR, GD, KBD). Any discrepancies/disagreement over eligibility of studies were discussed with reviewers and resolved based on consensus.

\section{Risk of bias (quality) assessment}

All selected eligible articles were reviewed independently by two reviewers (SD and EvT or another one reviewer). CASP checklists were used to assess the quality of studies. ${ }^{24}$ 
Any disagreements between reviewers were discussed and resolved with a third reviewer. The selected studies were appraised for strengths and weaknesses. The quality of evidence was assessed for each study. Studies with CASP score of more than 20 out of 33 were included in this review (Supplementary Table 4).

\section{Data synthesis}

A narrative synthesis was applied to the findings from the different studies included in this review. First, data were summarized and presented in a tabular form and discussed within the research team to ensure they were relevant. The narrative synthesis of the indications for CS and significant factors associated with CS was divided into the distinct categories using content analysis. ${ }^{25}$ The indications for CS and significant factors associated with CS was divided into medical/obstetrical and non-medical indications. Likewise, significant factors associated with
CS were classified into sociodemographic, medical/ obstetrical, and non-medical factors. Overview tables (Tables 1 and 2) were created to summarize the findings on indications and significant factors associated with $\mathrm{CS}$ in each category. Two researchers (SD and EvT/ another co-author) conducted the data synthesis. Lack of homogeneity and the amount of data meant that a meta-analysis was not feasible.

\section{RESULTS}

We identified a total of 1543 studies, of which 524 duplicates were removed using EndNote. Of 1019 studies, 925 studies were excluded after initial screening and a further 23 were removed after assessing the full text, leaving 71 which were assessed for quality. Three studies were excluded after the quality assessment (CASP score $<20$ ). We included 68 studies (Figure 1); 63 were cross-sectional

\begin{tabular}{|c|c|c|}
\hline Indications for CS & $\%$ & References \\
\hline \multicolumn{3}{|l|}{$\begin{array}{l}\text { 1. Medical and obstetrics Indications } \\
\text { Foetal Clinical Characteristics }\end{array}$} \\
\hline Foetal distress & $1.3-46 \%$ & $27-54,56,58-76,78$ \\
\hline Breech presentation & $2.38-16.8 \%$ & $28,30,31,35,37-40,42,44,45,50,54,56,58-61,65,66,69,70,75,76$ \\
\hline Malpresentation & $0.53-34.3 \%$ & $27,29-34,36,38,40,44,46,49,51-53,55,58,60,63,64,67-70,72-74,77$ \\
\hline Transverse/abnormal lie & $1.04-25.3 \%$ & $31,37,39,48,54,61,62,77$ \\
\hline IUGR & $0.52-9.31 \%$ & $28,30,31,33,42,44,48,49-54,56,58,61,63,65,68,69$ \\
\hline Post-term & $0.63-13 \%$ & $29,34,48,51,56,58,68,70,76$ \\
\hline Pre-term & $0.11-5.6 \%$ & $29,38,46,53,68$ \\
\hline Oligohydramnios & $0.1-27.9 \%$ & $27-31,33,35,36,38-40,44,48-52,54,58,59-62,64-70,75-77$ \\
\hline Meconium stained liquor & $9.6-32.4 \%$ & $37,40,59,71,75,77$ \\
\hline Multiple gestation/pregnancy & $0.32-3.5 \%$ & $29,30,31,32,35-39,42,44,46,48-51,54,55,58,59,61,63,65,66,68,69,70,73-75$ \\
\hline PROM & $1.1-6 \%$ & $28,29,46,50,51,58,62,68,70,76,77$ \\
\hline Cord presentation/prolapse & $0.1-4.2 \%$ & $30,31,36,37,44,47-49,53,60,66$ \\
\hline \multicolumn{3}{|l|}{ Maternal indications } \\
\hline$\cdot \mathrm{CPD}$ & $0.9-30.9 \%$ & $27,28,30-33,35,36-39,41,44,46,48-56,58-61,63-66,68-70,72,73,75,77$ \\
\hline • HDP & $0.21-15.8 \%$ & $27,28,34,37-40,42-44,46,48-52,54,56,58,60,61,63,65-68,70,72-76,78$ \\
\hline - APH/Placenta praevia/abruptio & $0.2-7.05 \%$ & $27,29-31,33,35-40,42,44,48-54,56,58-66,68-70,72-77$ \\
\hline - Scar tenderness & $1.5-31.22 \%$ & $38,42,41,54,69$ \\
\hline - Previous hysterotomy/myomectomy & $0.3 \%$ & $42,50,53,69$ \\
\hline - Medical disorders/ conditions & $0.2-5.8 \%$ & $29,30,31,38,39,42,44,49-51,53,58,60,61,63,67-70,73$ \\
\hline \multicolumn{3}{|l|}{ Obstetrics history } \\
\hline - Previous CS 1 or more & $2.9-48 \%$ & $27,28-48,50-52,54,56,58,59-70,72-77,78$ \\
\hline - Refuse of after CS (VBAC) & $2.85-22.4 \%$ & $38,41,42,69$ \\
\hline - History of subfertility/Infertility & $0.78-4.99 \%$ & $28.29,48,63$ \\
\hline - $\mathrm{BOH}$ & $0.29-5 \%$ & $29,31,33,37,38,42,44,46,48-50,52,60,63-65,67,68,70$ \\
\hline \multicolumn{3}{|l|}{ Labor abnormalities } \\
\hline - Obstructed Labor & $0.4-3.9 \%$ & $30,31,34,36,37,39,40,47,48,50,54,58,61,64,66,69,70,76$ \\
\hline - Prolonged Labour & $0.8-33.2 \%$ & $29,33,34,47,50,56,64,70,73,76$ \\
\hline$\cdot$ NPOL & $0.7-29 \%$ & $27,28,30,32,33,35-37,40,42,43,45,46,48,49,52-54,58-61,66-69,72,75,77,78$ \\
\hline - Failed induction & $0.40-15.7 \%$ & $27,28,30-33,36,37,39,40,43,44,46-53,56,58-60,63-66,68-71,75,77,78$ \\
\hline - Others & $0.5-36.2 \%$ & $34,35,37,39,40,47,52,60,75,76$ \\
\hline \multicolumn{3}{|l|}{ 2. Non-medical indications } \\
\hline Maternal request/demand & $0.1-3.97 \%$ & $29,37,42,56,66,67$ \\
\hline Labour pain & $0.2 \%$ & 70 \\
\hline Previous traumatic birth experience & $2.2 \%$ & 62 \\
\hline Precious pregnancy & $0.47-3.96 \%$ & $36,42,50,63,68$ \\
\hline No indication recorded & $0.6-8.9 \%$ & $68,70,73,76$ \\
\hline
\end{tabular}

IUGR: Intrauterine growth retardation, APH: Antepartum haemorrhage, CPD: Cephalopelvic disproportion, HPD: Hypertensive disorders of pregnancy, VBAC: vaginal birth after CS, BOH: Bad obstetric history, PROM: Premature rupture of membrane, NPOL: Non-progress of labor, CS: Caesarean section 
Table 2: Factors significantly associated with rising CS rates reported by studies in South Asia

\begin{tabular}{llcc} 
Category of factors & Significant associated factors & Total number of studies & References \\
\hline Socio-demographic & Higher age of mother & 8 & $34,39,88-93$ \\
factors & Higher education of mother & 7 & $34,39,88,90,92-94$ \\
& Urban residency & 3 & $88,92,94$ \\
& Higher socioeconomic status & 3 & $34,81,90$ \\
& Higher number of ANC visits & 3 & $34,39,90$ \\
& Place of birth: Private hospitals & 3 & 81,90 \\
& Obesity of mother & 2 & 91,92 \\
& Birth weight: $>$ 4 kilograms & 2 & 71,89 \\
& Low nutritional food intake during the pregnancy & 2 & 92,93 \\
& Lower birth order & 2 & 34,93 \\
Not using contraceptive method & 1 & 93 \\
Medical and & Length of baby >45 centimeters & 1 & 93 \\
obstetric factors & Distance to health facility & 1 & 39 \\
& Previous CS & 3 & $39,92,93$ \\
& Complications in pregnancy and childbirth & 3 & $88,90,93$ \\
& Lower parity: Nullipara or primipara & 3 & $39,89,94$ \\
& Gestational week (pre or post) & 2 & 81,89 \\
Prolong labour & 2 & 71,93 \\
& Multiple pregnancy/birth & 1 & 90 \\
Bishop's score 5 or less & 1 & 71 \\
Abnormal foetal presentation & 1 & 89 \\
Bad obstetric history (Foetus loss) & 1 & 34 \\
& Umbilical cord prolapse & 1 & 91 \\
& Three doses misoprostol in labour induction & 1 & 71
\end{tabular}

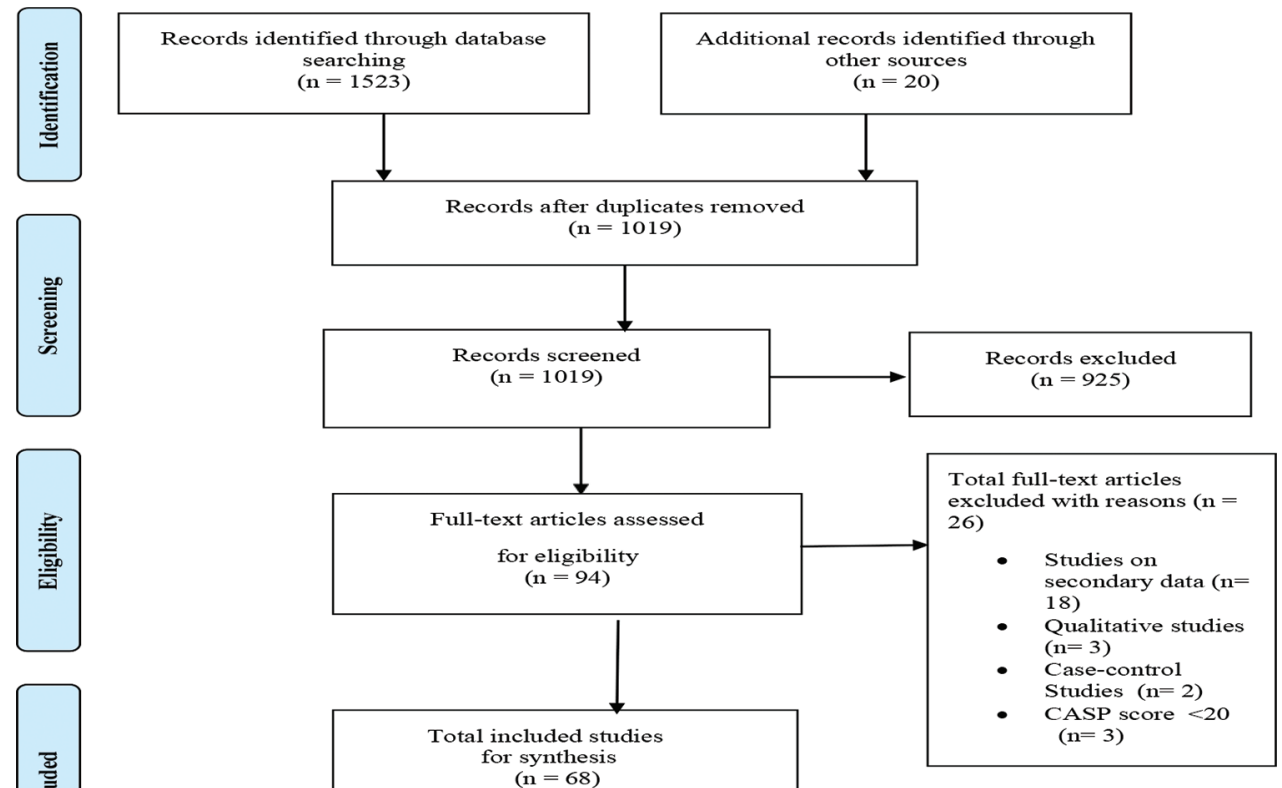

Figure 1: PRISMA flow diagram ${ }^{26}$

studies and 5 were cohort studies. Almost all included studies applied a quantitative approach $(n=67)$ and one was a mixed methods study.
A total 61 studies illustrated the indications for CS, and 11 described factors which were significantly associated with rising CS (4 out of 11 studies reported both indications and 
significant associated factors). Figure 1 shows the Preferred Reporting Items for Systematic Reviews and Meta-analysis flow diagram ${ }^{26}$ of the progress.

\section{Indications for CS in South Asia}

We divided indications for CS into two categories: medical/obstetrical and non-medical. The medical/ obstetrical indications were further divided into fetal clinical characteristics, maternal clinical characteristics, obstetric history, labor abnormalities and other.

\section{Key indications for overall CS}

A total 51 studies ${ }^{27-78}$ reported the overall indications for CS (Table 1). More details are given in Supplementary Tables 2 and 5 .

\section{Medical and obstetric indications}

Fetal distress is the most common key indicator for CS followed by previous CS, antepartum hemorrhage $(\mathrm{APH})$ including placenta previa/placenta abruption, cephalopelvic disproportion (CPD), failed induction, oligohydramnios, hypertensive disorders of pregnancy (HDP) (pregnancy-induced hypertension, pre-eclampsia, and eclampsia), non-progress of labor (NPOL), multiple pregnancy, fetal malpresentation, breech presentation and intrauterine growth retardation (IUGR) (Table 1).

Many studies ${ }^{34,35,37,39,40,47,52,60,75,76}$ categorized some indications to other indication/miscellaneous (0.5-36.2\%). Some studies used vague terminology such as maternal indication, fetal indication, obstetric indication ${ }^{32,53,55}$ antepartum complications. ${ }^{41}$ Similarly, there is evidence of use of non-standardized terminology/abbreviations for some indications such as "DLOC with head floating." ${ }^{11}$ These unspecified and vague indications are not included in the overview table.

Non-medical indications

The non-medical indications included maternal request/ choice/demand, ${ }^{29,37,42,56,66,67}$ precious pregnancy, ${ }^{36,42,50,63,68}$ labor pain, ${ }^{70}$ previous traumatic birth experiences. ${ }^{62} \mathrm{CS}$ performed without indication $(0.6-8.9 \%)$ was also apparent (Table 1$)$.

\section{Key indications for elective CS and emergency CS}

A total 16 studies ${ }^{29,40,42,49,57,58,65,70,73,74,77,79-83}$ reported the indications for elective CS. The most common indication for elective CS was previous CS $(9.4-78.72 \%){ }^{29,40,42,49,57,58,65,70,73,74,77,79-}$ 82 followed by malpresentation, $40,29,49,57,58,70,73,74,77,80,82,83$ CPD, ${ }^{43,49,57,65,70,73,79,80-83}$ HDP, $29,42,49,57,65,70,73,74,80,83$ maternal medical conditions, ${ }^{29,42,43,49,58,70,73,80,82,83} \mathrm{APH} /$ placenta previa/abruptio, ${ }^{29,42,49,57,65,73,74,80,82}$ oligo/severe oligohydramnios, ${ }^{49,57,65,70,77,80,82,84}$ breech, ${ }^{40,42,49,57,58,65,70}$ multiple pregnancy, ${ }^{29,57,58,70,80,82} \operatorname{IUGR}^{42,49,65,80,82,83}$ bad obstetric history $(\mathrm{BOH}),{ }^{29,43,49,57,65,70,79}$ and post-term..$^{42,58,70,78}$ History of subfertility, ${ }^{29,43,83,84}$ and elderly mother/primipara, ${ }^{43,70,82}$ were notable indications for elective CS. Non-medical indications were maternal request, ${ }^{29,57}$ and precious pregnancy, ${ }^{80,83}$ in elective CS. Two studies ${ }^{70,73}$ showed that $0.6-5.6 \%$ elective CS was performed without indication.

Similarly, a total of 16 studies $^{40,42,43,49,57,58,65,70,73,74,77,79-81,83,85}$ reported indications for emergency CS. The most common indication for emergency CS was fetal distress $(7.7-61 \%)^{40,42,43,49,57,58,65,70,73,74,77,80,81,83,85}$ followed by previous CS, $42,49,57,58,65,70,73,74,77,79,80,85$ PIH (Pregnancy-Induced Hypertension)/pre-eclampsia/eclampsia, ${ }^{42,49,57,58,65,70,73,74,80,85}$ APH/Placenta previa/abruption, ${ }^{49,57,58,65,70,73,74,77,80,85}$ malpresentation, ${ }^{40,49,57,58,70,73,74,77,80,83} \mathrm{CPD},{ }^{49,57,58,65,70,73,80,83,85}$ NPOL, ${ }^{40,42,43,44,57,58,77,79,81}$ oligohydramnios, ${ }^{49,58,65,70,77,79,80,83}$ breech, ${ }^{40,42,49,57,58,65,70}$ multiple pregnancy, ${ }^{57,58,65,70,73,74,80}$ obstructed labor, ${ }^{49,57,58,70,80,85}$ failed induction, ${ }^{43,57,58,65,70,79}$ cord presentation, ${ }^{49,57,74,70}$ and medical disorders, ${ }^{42,70,80,85}$ Precious pregnancy, ${ }^{80,83}$ and labor pain ${ }^{70}$ were non-medical indications in emergency CS. Surprisingly, one study ${ }^{73}$ reported that $7.9 \%$ of emergency CS were performed without indication (See more details in Supplementary Tables 2 and 6).

\section{Key indications in terms of primary CS and repeat CS}

Eight studies $50,55,67,70,80,83,84,86$ illustrated the indications for primary CS. The most common indication for primary CS was fetal distress $(5.58-60.8 \%),{ }^{50,55,67,70,80,83,86}$ followed by CPD, ${ }^{50,55,70,80,83,84,86}$ malpresentation, ${ }^{55,67,80,83,84} \mathrm{HDP}, 50,67,80,84,85$ NPOL, ${ }^{67,70,80,84,85}$ obstructed labor, ${ }^{50,70,80,84,85}$ failed induction, ${ }^{70,80,84,85} \mathrm{APH} /$ placenta previa/abruptio, ${ }^{50,80,84,86}$ and oligohydramnios, ${ }^{80,83,84,86}$ precious pregnancy, ${ }^{80,83,84,86}$ and maternal request, ${ }^{67,82}$ were non-medical indications for primary CS.

Similarly, a total of seven studies ${ }^{44,48,50,55,70,80,83}$ illustrated the indications for repeat CS. The most common indications for repeat CS were previous CS $(1.31-48.5 \%),{ }^{44,48,50,55,70,83}$ fetal distress, ${ }^{44,48,50,55,80,83} \mathrm{CPD},{ }^{44,48,50,55,80,83}$ scar tenderness, ${ }^{44,48,55,80,83}$ breech, ${ }^{44,48,55,80,83}$ and multiple pregnancy, ${ }^{44,48,50,55,80}$ oligohydramnios, ${ }^{44,48,80,83} \mathrm{IUGR},{ }^{44,48,80,83} \mathrm{HDP},{ }^{44,48,50,80} \mathrm{APH} /$ placenta previa/abruption, ${ }^{44,48,50,80}$ medical disorders, ${ }^{44,48,80,83}$ big baby, ${ }^{44,48,83}$ and malpresentation. ${ }^{44,48,50}$ precious pregnancy, ${ }^{80,83}$ was given as a non-medical indication for repeat CS (See details in Supplementary Tables 2 and 7).

\section{Key indications in terms of parity}

Seven studies ${ }^{43,58,62,70,82,86,87}$ illustrated the indications for CS in primigravidae. The most common indication for CS in primiparous women was fetal distress $(8.3-53 \%),{ }^{43,58,62,70,86,87}$ followed by CPD, ${ }^{43,58,70,82,86}$ oligohydramnios, ${ }^{58,62,82,86}$ abnormal fetal lie, ${ }^{62,82,86}$ breech, ${ }^{58,82,86}$ IUGR, ${ }^{58,82,86} \mathrm{HDP},{ }^{82,86,87}$ placenta previa/abruptio, ${ }^{62,82,86} \mathrm{NPOL},{ }^{43,86,87}$ Obstructed 
labor, ${ }^{58,86,87}$ and failed induction. ${ }^{43,86,87}$ Elderly primipara/ elderly mother ${ }^{43,82}$ and subfertility, ${ }^{43,82}$ were also indications for CS in primiparous women. Precious pregnancy, ${ }^{86,87}$ and patient request ${ }^{87}$ were non-medical indications for CS in primiparous women.

Similarly, four studies ${ }^{43,58,62,86}$ presented the indications for CS in multigravida. Fetal distress $(11.4-61 \%)^{43,58,62,86}$ was the most common indication for CS in multiparous women followed by oligohydramnios, ${ }^{58,62,86}$ failed induction, ${ }^{43,63,86}$ breech, ${ }^{58,86}$ abnormal fetal lie, ${ }^{62,86}$ premature rupture of membrane (PROM), ${ }^{62,86}$ IUGR, ${ }^{58,86} \mathrm{CPD},{ }^{58,86}$ placenta previa/abruptio, ${ }^{62,86}$ obstructed labor, ${ }^{58,86}$ NPOL. ${ }^{43,58}$ Traumatic experience in previous childbirth ${ }^{62}$ was a nonmedical indication in multiparous women (See more details in Supplementary Tables 2 and 8).

\section{Factors significantly associated with rising CS rates} in South Asia

Several significant factors associated with rising CS rates were reported in South Asia (Table 2). These factors are divided into three major categories: (1) sociodemographic; (2) medical and obstetric; and (3) non-medical factors. (See more details in Supplementary Table 3).

\section{Sociodemographic factors}

We found that higher maternal age ${ }^{34,39,88-93}$ and higher maternal education $34,39,88,90,92,93,94$ were the key factors significantly associated with rising CS rate in South Asia. Other factors significantly associated CS included urban residency, ${ }^{88,92,94}$ higher economic status, ${ }^{34,81,90}$ and higher number of antenatal clinic (ANC) visits, ${ }^{34,39,90}$ childbirth in a private hospital, ${ }^{81,90}$ birthweight of baby $(>4 \mathrm{~kg}),{ }^{71,89}$ low nutritional food intake during the pregnancy, ${ }^{92,93}$ lower birth order, ${ }^{34,93}$ not using contraceptive method, ${ }^{93}$ length of baby $(>45 \mathrm{~cm})^{93}$ and distance to health facility ${ }^{39}$ (Tables 2$)$.

\section{Medical/obstetric factors}

Previous CS, ${ }^{39,92,93}$ complications in pregnancy and childbirth, ${ }^{88,90,93}$ lower parity (nullipara), ${ }^{88,90,93}$ gestational week (pre or post) ${ }^{81,89}$ prolonged labor, ${ }^{71,93}$ multiple pregnancy, ${ }^{90}$ abnormal fetal presentation, ${ }^{89} \mathrm{BOH}$ (fetal loss), ${ }^{34}$ umbilical cord prolapse, ${ }^{91}$ and 3 doses misoprostol used in labor induction ${ }^{71}$ were medical/obstetric factors that significantly associated with rising CS rates in South Asia (Tables 2).

\section{Non-medical factors}

Regarding non-medical factors for rising CS rates in South Asia, patients' preference for CS, increasing number of private hospitals, the poor condition of public hospitals and the unavailability of good quality health care in rural areas were reported ${ }^{91}$ (Tables 2).

\section{DISCUSSION}

This systematic review reports various key indications for performing CS and several factors significantly associated with rising CS rates in South Asia.

\section{Key indications for CS in South Asia}

Fetal distress is found to be the major key indication for performing CS in this review as reported by other studies. ${ }^{20,95-98}$ Fetal distress is an emergency condition; however, it was given as an indication also for performing elective CS in some studies. ${ }^{42,43,49,73,79}$ Early and accurate diagnosis of fetal distress can reduce the risk of perinatal mortality. Fetal heart rate monitoring and partograph are fundamental to diagnose fetal distress and progress of labor, but Litorp et al., ${ }^{23}$ identified that fetal heart rate monitoring was only performed in one-third (36\%) of total CS cases. However, the diagnosis of fetal distress is notoriously difficult. Shortage of resources such as staff (obstetricians/qualified midwives) ${ }^{70}$ and shortage of diagnostic resources in most parts of South Asia may add to the imprecision of the diagnosis of fetal distress.

Previous CS was another key indication for CS; ${ }^{95,96}$ for both elective ${ }^{97}$ and repeat CS. ${ }^{99}$ Recent studies have reported that previous CS is the key leading indication of CS. ${ }^{22,100-103}$ The growing number of primary CS may influence the decisionmaking around mode of birth. The majority of pregnant women who have a history of previous CS would decline vaginal birth after CS (VBAC). ${ }^{96,97,99}$ Although trial of VBAC is often the best option, it may be riskier than repeating CS where resources are lacking, and repeat CS may be the first choice in low-resource countries like South Asia. ${ }^{104}$ This is because successful VBAC depends on many factors such as clinical expertise; resources; good obstetric history and positive attitude of women who are going through the VBAC; proper management of fear and providing unbiased information to women. Unfortunately, these criteria for VBAC are often scarce in most places in low-resource countries. ${ }^{104}$

As reported by several previous studies, our review documents many other common key indications for CS: APH/placenta previa/abruption, ${ }^{22,96,101,103} \mathrm{CPD}, 22,95,96,100,103$ HDP, ${ }^{22,95,96,103}$ failed induction, ${ }^{22,96,100,103}$ NPOL, ${ }^{95,96,100-103}$ oligohydramnios, ${ }^{95,100,103}$ multiple pregnancy, ${ }^{22,95,101,103}$ malpresentation, ${ }^{95,96}$ breech presentation, ${ }^{22,100,103}$ and IUGR, ${ }^{95,101}$ Similarly, CPD is found to be a key indicator for elective CS. $.5,97,98$ emergency CS, ${ }^{95,96,98}$ primary CS, ${ }^{99}$ repeat $\mathrm{CS}^{99}$ and CS in primigravida. ${ }^{20} \mathrm{HDP}$ was reported as a key indication for elective CS, ${ }^{95,98}$ emergency CS, ${ }^{95,97,98}$ primary $\mathrm{CS},{ }^{99}$ repeat $\mathrm{CS},{ }^{99} \mathrm{CS}$ in primigravidae, ${ }^{99}$ and multigravida. ${ }^{99}$

APH/placenta previa/abruptio was also a key indication for elective $\mathrm{CS},{ }^{97,98}$ primary $\mathrm{CS},{ }^{99}$ repeat $\mathrm{CS},{ }^{99}$ 
CS in primigravida, ${ }^{99}$ and multigravida..${ }^{99,105}$ Similarly, oligohydramnios was common indication for elective CS, $, 5,98$ emergency CS, ${ }^{97,98}$ primary CS, ${ }^{99}$ repeat $\mathrm{CS},{ }^{96} \mathrm{CS}$ in primigravida, ${ }^{99}$ and multigravida. ${ }^{99,105}$ Breech presentation was a common indication for elective CS, ${ }^{98}$ emergency $\mathrm{CS},{ }^{98}$ primary CS, repeat $\mathrm{CS},{ }^{96,99} \mathrm{CS}$ in primigravida and multigravida. ${ }^{105}$ IUGR was also a common indication for elective CS, ${ }^{98}$ emergency $\mathrm{CS},{ }^{98}$ primary $\mathrm{CS}$, repeat $\mathrm{CS},{ }^{99}$ CS in primigravida and multigravida. ${ }^{105}$ Similarly, other common indications were: malpresentation (elective CS, ${ }^{98}$ emergency $\mathrm{CS},{ }^{97,98}$ primary $\mathrm{CS},{ }^{99}$ repeat $\mathrm{CS},{ }^{99}$ fail induction (emergency CS, ${ }^{95,98}$ primary CS, ${ }^{99}$ multigravida,${ }^{99}$ multiple pregnancy (elective CS, ${ }^{98}$ emergency $\mathrm{CS},{ }^{99}$ primary $\mathrm{CS}$, and repeat $\mathrm{CS},{ }^{99}$ ), obstructed labor ${ }^{105}$ (emergency CS, primary CS, CS in primigravida and multigravida), NPOL (emergency $\mathrm{CS}^{95}$ and primary $\mathrm{CS}^{99}$ and maternal medical conditions (elective CS, ${ }^{98}$ and emergency $\mathrm{CS}^{96}$ ), $\mathrm{BOH}^{98}$ was key indication for elective CS and cord presentation ${ }^{98}$ was for emergency CS. Scar tenderness ${ }^{96}$ and large baby were also key indications for repeat CS.

Subfertility ${ }^{98,99}$ and advanced maternal age, ${ }^{20,99}$ were found to be notable indications for elective CS and CS in primigravidae. A history of infertility in nulliparous women can increase the risk of childbirth by CS. ${ }^{106}$ Increasing education, empowerment, and improved socioeconomic status of women in South Asia may encourage them to consider pregnancy at an advanced age. This may also be associated with pregnancy complications and increase the risk of CS. ${ }^{107}$

Maternal request was a major non-medical indication for CS. ${ }^{95,99,101,102}$ Indications for elective CS are increasingly likely to be for psychological indications. ${ }^{108}$ Women may perceive CS as a safer and easier way of giving birth because of fear of labor pain and fear of loss of baby. ${ }^{109}$ Schantz et al., ${ }^{110}$ revealed that pregnant women are not well informed in the process of giving consent for CS. Lack of knowledge on mode of childbirth may lead to wrong choices in their birth plan. ${ }^{110-112}$ In addition, women may feel pressurized to request $\mathrm{CS}$ for fetal well-being, cosmetic reasons, maintain pelvic floor damage or sexual satisfaction rather than to protect their autonomy or own reproductive rights. ${ }^{111}$

In this review, CS performed with no stated indications $(0.6-8.9 \%)$ was also apparent. ${ }^{68,70,73,76}$ Such surgical procedures do not only affect maternal and neonatal health adversely, but also add unnecessary costs to the family and the misuse of precious health resources. Furthermore, we found some vague terminology used for indications; along with the use of non-standardized terminology/ abbreviations; and indications of CS categorized as "other." These are difficult to understand/interpret thus reflect poor practice. The data highlight the necessity of adherence to locally tailored comprehensive guidelines and evidencebased practice in obstetric care.

\section{Factors associated with rising CS in South Asia}

Higher maternal age is found to be the most common key contributing factors for rising CS rates in South Asia as reported by several studies. ${ }^{12,13,18,113-116}$ Increased maternal age can increase the risk of assisted reproductive technology, gestational diabetes/diabetes mellitus, preeclampsia and placenta previa/placental abruption. ${ }^{107}$ It can be argued that increasing empowerment and improving socioeconomic status of women in South Asia possibly encourage them to consider pregnancy at an advanced age. Similarly, higher education of the mother is found to be another key factor significantly associated with increasing CS rates. ${ }^{12,13,18,19,21,113,115}$ Increasing the educational status of women has offered them independence as well as more control over their birth plan, however, better education of women may not provide them with better knowledge of the risks and benefits of CS or mode of childbirth. ${ }^{112}$

Place of residency (urban residency) is significantly associated with the rising CS rate. ${ }^{12,13,18,19,21,116}$ The availability of modern obstetric care private facilities in urban areas probably encourage women to utilise modern technology for childbirth by CS. ${ }^{112}$ This is also true of the higher economic status of women. . $^{12,18,19,21,113,116}$ Richer/richest women or families have more choices of obstetric services and could afford the cost of CS. Similarly, higher number of ANC check-up ( 3 or more visits) is also found to be a factor significantly associated with rising CS..$^{12,112,114,115}$ Lack of adequate counselling on mode of childbirth or/and lack of information on risk versus benefits of CS perhaps encourage pregnant women to choose CS. ${ }^{117}$ Recently, Doraiswamy and colleagues ${ }^{118}$ reported that inadequate communication between physicians and pregnant women is one of the factors for the rising CS rate in Bangladesh. Childbirth in private hospitals/place of birth is also found to be a significantly associated with rising CS rate in South Asia as claimed by previous studies. ${ }^{13,15,18,114,115,119}$ Private care providers perhaps motivate pregnant women by suggesting CS is an easy and safe way to give birth. ${ }^{117}$

History of previous CS is found to be the most common medical/obstetrics factor significantly associated with rising CS in South Asia. Previous CS is a strong predictor of repeat CS. ${ }^{120}$ This highlights the need to avoid primary $\mathrm{CS}$ wherever possible and the need for antenatal education. Similarly, complications in pregnancy are also found to be common significant medical factors associated with rising CS rates. In Bangladesh, Karim et al., ${ }^{119}$ also found that CS was 3.6 times higher among women who reported complications during the last birth than those who did not report any complication. Adherence to evidence-based 
guidelines on indications for CS is essential in considering whether these factors are sufficient reason for preforming $\mathrm{CS}$ in any individual case.

Maternal preference for CS is one of the most significant non-medical factors for rising CS rates. Wealthy urban women perceives CS either as a modern childbirth method or lifestyle choice as in Bangladesh. ${ }^{112}$ Higher maternal age, education and socioeconomic status of women as well as residing in urban areas appear to be correlated with maternal preference of CS. In addition, lack of adequate knowledge about risks, benefits of mode of childbirth, and medical indications of $\mathrm{CS}^{110,112,117}$ along with poor communication between obstetricians and women ${ }^{118}$ possibly boost the maternal preference of CS.

Increasing numbers of private hospitals are associated with rising CS rates. Private healthcare is a fast-growing business in South Asia and may partly be to blame for the rising CS rate. A qualitative study conducted in India revealed that private providers would accept maternal request and perform more CS to be commercially successful. ${ }^{121}$ Private health facilities contribute to rising CS rates in India, ${ }^{15,16}$ Nepal, ${ }^{18}$ and Bangladesh. ${ }^{117,121}$

\section{Limitations of the study}

The review has not included qualitative studies, casecontrol studies, studies based on secondary analysis and other interventional studies. Importantly, it only includes studies reported in English. Similarly, meta-analysis or other statistical analysis of data could not be performed because of heterogeneous data. There were no eligible studies from Bhutan and Maldives for this review. Further studies are needed to consider the contribution of evidence from qualitative and interventional studies.

\section{CONCLUSION}

This review reveals key indications for performing CS and their significant factors in South Asia. It concludes that fetal distress and previous CS are the most common key medical indications followed by $\mathrm{APH} /$ placenta previa/abruptio, CPD, HDP, failed induction, NPOL, oligohydramnios, multiple pregnancy, malpresentation, breech presentation, and IUGR. Fetal distress was a prime indication for all types of CS except elective CS. Previous CS was the chief indication for elective and repeat CS. CPD is found to be a key indicator also for elective/emergency/primary/repeat CS and CS in primigravida. HDP was reported as a key indication also for elective/emergency/primary/repeat CS, CS in primigravida and multigravida. Maternal request is the most important non-medical indication for CS. The use of imprecise terminology for indications of CS and carrying out CS without indication were also apparent. Higher maternal age, higher maternal education, urban residency, higher economic status, higher numbers of ANC visits, previous CS, complications of pregnancy/childbirth, and lower parity are found to be the most common factors significantly associated with rising CS rates in South Asia. Maternal preference for CS and rising numbers of private hospitals are found to be the most important non-medical factors significantly associated factors for rising CS rates in South Asia. These key indicators and significant factors reflect global trends of CS and suggest that a global strategy is required to stem the rise of unnecessary CS. Realistic and candid explanations to pregnant women and their family regarding the benefits of vaginal birth for women and babies should form an integral part of maternity care as these are issues of public health. The strategies for optimizing the use of CS should include greater precision in diagnosis of fetal distress; keeping primary CS to a minimum; educating pregnant women/family on indications, risks and benefits of CS; avoiding CS for non-medical reasons; and adherence to evidence-based guidelines for CS.

\section{ACKNOWLEDGMENTS}

The authors would like to thank Mr. Caspian Dugdale and Ms. Astha Dhakal for their help in this review.

\section{REFERENCES}

1. Appropriate technology for birth. Lancet. 1985;2(8452):436-437. https://doi.org/10.1016/S0140-6736(85)90673-7

2. Boerma T, Ronsmans C, Melesse DY, Barros AJ, Barros FC, Juan L, et al. Global epidemiology of use of and disparities in caesarean sections. Lancet. 2018;392(10155):1341-1348.

https://doi.org/10.1016/S0140-6736(18)31928-7

3. World Health Organization. WHO Statement on Caesarean Section Rates. Geneva: World Health Organization; 2015. Available from: https://www.apps.who.int/iris/bitstream/ handle/10665/161442/who_rhr_15.02_eng.pdf;sequence=1 [Last accessed on 2020 Mar 20].

4. Betrán AP, Torloni MR, Zhang JJ, Gülmezoglu AM and WHO Working Group on Caesarean Section. WHO statement on caesarean section rates. BJOG. 2016;123(5):667-670.

https://doi.org/10.1111/1471-0528.13526

5. Ye J, Betrán AP, Torloni MR, Mikolajczyk RT, Gulmezoglu A and Zhang J. Association between caesarean section and maternal and neonatal mortality: A worldwide population-based ecologic study. BJOG. 2015;123(5):745-753.

https://doi.org/10.1111/1471-0528.13592

6. Souza JP, Gülmezoglu AM, Lumbiganon P, Laopaiboon M, Carroli G, Fawole B, et al. Caesarean section without medical indications is associated with an increased risk of adverse shortterm maternal outcomes: The 2004-2008 WHO global survey on maternal and perinatal health. BMC Med. 2010;8(1):71. https://doi.org/10.1186/1741-7015-8-71

7. Sandall J, Tribe RM, Avery L, Mola G, Visser GH, Homer CS, et al. Short-term and long-term effects of caesarean section on the health 
of women and children. Lancet. 2018;392(10155):1349-1357. https://doi.org/10.1016/S0140-6736(18)31930-5

8. Marshall NE, Fu R and Guise JM. Impact of multiple cesarean deliveries on maternal morbidity: A systematic review. Am J Obstet Gynaecol. 2011;205(3):262.e1-261.e8. https://doi.org/10.1016/j.ajog.2011.06.035

9. Gibbons L, Belizán JM, Lauer JA, Betrán AP, Merialdi M and Althabe $F$. The global numbers and costs of additionally needed and unnecessary caesarean sections performed per year: Overuse as a barrier to universal coverage. World Health Rep. 2010;30(1):1-31.

10. Lumbiganon P, Laopaiboon M, Gulmezoglu AM, Souza JP, Taneepanichskul S, Ruyan P, et al. Method of delivery and pregnancy outcomes in Asia: The WHO global survey on maternal and perinatal health 2007-08. Lancet. 2010;375(9713):490-499. https://doi.org/10.1016/S0140-6736(09)61870-5

11. Dhakal-Rai S, Poobalan A, Jan R, Bogren M, Wood J, Dangal G, et al. Caesarean Section rates in South Asian cities: Can midwifery help stem the rise? JAM. 2019;6(2):4-22.

12. Khan MN, Islam MM, Shariff AA, Alam MM and Rahman MM. Socio-demographic predictors and average annual rates of caesarean section in Bangladesh between 2004 and 2014. PloS One. 2017;12(5):e0177579.

https://doi.org/10.1371/journal.pone.0177579

13. Verma V, Vishwakarma RK, Nath DC, Khan HT, Prakash R and Abid O. Prevalence and determinants of caesarean section in South and South-East Asian women. PLoS One. 2020;15(3):e0229906. https://doi.org/10.1371/journal.pone.0229906

14. Guilmoto $\mathrm{CZ}$ and Dumont $\mathrm{A}$. Trends, regional variations, and socioeconomic disparities in cesarean births in India, 2010-2016. JAMA Netw Open. 2019;2(3):e190526.

https://doi.org/10.1001/jamanetworkopen.2019.0526

15. Singh $P$, Hashmi $G$ and Swain PK. High prevalence of cesarean section births in private sector health facilities- analysis of district level household survey-4 (DLHS-4) of India. BMC Public Health. 2018;18(1):613-613.

https://doi.org/10.1186\%2Fs12889-018-5533-3

16. Lee HY, Kim R, Oh J and Subramanian SV. Association between the type of provider and cesarean section delivery in India: A socioeconomic analysis of the national family health surveys 1999, 2006, 2016. PLoS One. 2021;16(3):e0248283. https://doi.org/10.1371/journal.pone.0248283

17. Rai SD, Regmi P, van Teijlingen E, Wood J, Dangal G and Dhakal K. Rising rate of caesarean section in Urban Nepal. J Nepal Health Res Counc. 2019;16(41):479-480.

https://doi.org/10.33314/jnhrc.v16i41.1750

18. Bhandari AK, Dhungel $B$ and Rahman M. Trends and correlates of caesarean section rates over two decades in Nepal. BMC Pregnancy Childbirth. 2020;20(1):763.

https://doi.org/10.1186/s12884-020-03453-2

19. Mumtaz S, Bahk J and Khang YH. Rising trends and inequalities in cesarean section rates in Pakistan: Evidence from Pakistan demographic and health surveys, 1990-2013. PLoS One. 2017;12(10):e0186563.

https://doi.org/10.1371/journal.pone.0186563

20. Goonewardene M, Peiris M, Kariyawasam S, Mallawaaratchi S, Kadawathage D, Sanjeewa L, et al. Analysis of high caesarean section rates: The second step after audits using the ten group classification system. Ceylon Med J. 2017;62(3):149-158. https://doi.org/10.4038/cmj.v62i3.8518

21. Mumtaz S, Bahk $\mathrm{J}$ and Khang $\mathrm{YH}$. Current status and determinants of maternal healthcare utilization in Afghanistan:
Analysis from Afghanistan demographic and health survey 2015. PLoS One. 2019;14(6):e0217827.

https://doi.org/10.1371/journal.pone.0217827

22. Dorji T, Wangmo K, Dorjey Y, Dorji N, Chhetri DK, Tshering S, et al. Indications and factors associated with cesarean section in Bhutan: A hospital-based study. Int J Gynecol Obstet. 2021;153(3):520-526. https://doi.org/10.1002/ijgo.13506

23. Litorp $H$, Gurung R, Målqvist $M$ and $K c$ A. Disclosing suboptimal indications for emergency caesarean sections due to fetal distress and prolonged labor: A multicenter cross-sectional study at 12 public hospitals in Nepal. Reprod Health. 2020;17(1):197. https://doi.org/10.1186\%2Fs12978-020-01039-x

24. Critical Appraisal Skills Programme (CASP) Checklist; 2018. Available from: https://www.casp-uk.net/casp-toolschecklists. Accessed on 30/06/2019.

25. Stemler SE. In: Scott R and Kosslyn S, editors. Content Analysis: Emerging Trends in the Social and Behavioral Sciences. New York, United States: Wiley; 2015. p. 1-4. https://doi.org/10.1002/9781118900772.etrds0053

26. Moher D, Liberati A, Tetzlaff J,Altman DG and Prisma G. Preferred reporting items for systematic reviews and meta-analyses: The PRISMA statement. PLoS Med. 2009;6(7):e1000097. https://doi.org/10.1371/journal.pmed.1000097

27. Acharya S and Raut B. A descriptive analysis of the indications for caesarean section in Lumbini Zonal Hospital, Butwal. J Univ Coll Med Sci. 2017;5(2):31-24.

https://doi.org/10.3126/jucms.v5i2.19161

28. Amatya A, Paudel R, Poudyal A, Wagle RR, Singh M and Thapa S. Examining stratified cesarean section rates using Robson classification system at Tribhuvan University Teaching Hospital. J Nepal Health Res Counc. 2013;11(25):255-258. https://doi.org/10.33314/jnhrc.v0i0.400

29. Ara I, Sultana R, Solaiman SM, Hassain MS. Current trend of caesarean section in a Tertiary Care Military Hospital. Bangladesh Med Res Counc Bull. 2018;44(1):15-22.

https://doi.org/10.3329/bmrcb.v44i1.36800

30. Bade P, Kendre V, Jadhav Y, Wadagale A. An analysis of indications for caesarean section at government medical college, Latur. Int J Recent Trends Sci Technol. 2014;11(1):6-8.

31. Bala S, Patidar BL, Gupta B. A retrospective analysis of annual cesarean section rate in a Tertiary Care Hospital, KOTA. J Med Sci Clin Res. 2017;5(7):25325-25329. https://doi.org/10.18535/jmscr/v5i7.168

32. Banerjee A, Bhadra B and Dey KR. Analysis of caesarean section in a tertiary care hospital, Assam, India. Int J Reprod Contracept Obstet Gynecol. 2018;7(4):1515. https://doi.org/10.18203/2320-1770.IJRCOG20181346

33. Bhandari BR. Indications and fetal outcomes of caesarean section in Sindhu Sadabahar Hospital, Sindhupalchok. KUMJ. 2017;15(60):284-287.

34. Begum T, Rahman A, Nababan H, Hoque DM, Khan AF, Ali T, et al. Indications and determinants of caesarean section delivery: Evidence from a population-based study in Matlab, Bangladesh. PLoS One. 2017;12(11):e0188074. https://doi.org/10.1371/journal.pone.0188074

35. Chaudhary R, RautKB and Pradhan K. Prevalence and indications of cesarean section in a community hospital of Western Region of Nepal. J Nepal Med Assoc. 2018;56(213):871-874.

36. Chavda D, Goswam K and Dudhrejiya K. A cross sectional study of 1000 lower segment cesarean section in obstetrics and gynecology department of PD U Medical College, Rajkot, Gujarat, India. Int J Reprod Contracept Obstet Gynecol. 
2017;6(4):1186-1191

https://doi.org/10.18203/2320-1770.ijrcog20170916

37. Chhetri S and Singh U. Caesarean section: Its rates and indications at a tertiary referral center in Eastern Nepal. Health Renaissance. 2011;9(3):179-183.

https://doi.org/10.3126/hren.v9i3.5587

38. Das RK, Subudhi KT and Mohanty RK. The rate and indication of caesarean section in a tertiary care teaching hospital eastern India. Int J Contemp Pediatr. 2018;5(5):1733-1739. https://doi.org/10.18203/2349-3291.ijcp20182963

39. Desai G, Anand A, Modi D, Shah S, Shah K, Shah A, et al. Rates, indications, and outcomes of caesarean section deliveries: A comparison of tribal and non-tribal women in Gujarat, India. PLoS One. 2017;12(12):e0189260.

https://doi.org/10.1371/journal.pone.0189260

40. Dhakal KB, Dhakal S and Bhandari S. Profile of caesarean section in Mid-Western Regional Hospital in Nepal. J Nepal Health Res Counc. 2018;16(1):84-88.

41. Dhodapkar SB, Bhairavi S, Daniel M, Chauhan NS and Chauhan RC. Analysis of caesarean sections according to Robson's ten group classification system at a tertiary care teaching hospital in South India. Int J Reprod Contracept Obstet Gynecol. 2015;4(3):746.

https://doi.org/10.18203/2320-1770.ijrcog20150085

42. Ehtisham $\mathrm{S}$ and Hashmi HA. Determinants of caesarean section in a tertiary hospital. J Pak Med Assoc. 2014;64(10):1175-1178.

43. Goonewardene M. Audit: The strategy to reduce the rising cesarean section rates. J South Asian Fed Obstet Gynaecol. 2012;4(1):5-9.

44. Gupta M and Garg V. The rate and indications of caesarean section in a tertiary care hospital at Jaipur, India. Int J Reprod Contracept Obstet Gynecol. 2017;6(5):1786-1792.

https://doi.org/10.18203/2320-1770.ijrcog20171530

45. Hafeez M, Yasin A, Badar N, Pasha MI, Akram N and Gulzar B. Prevalence and indications of caesarean section in a teaching hospital. JIMSA. 2014;27(1):15-16.

46. Gurung RT, Gurung G, Shrestha R, Gurung T and Sharma P. Prevalence and outcome of cesarean section at Gandaki Medical College teaching hospital and research centre, Pokhara, Nepal. J Gandaki Med Coll. 2016;9(2):1-6. https://doi.org/10.3126/jgmcn.v9i2.17858

47. Ishaq R, Baloch NS, Iqbal Q, Saleem F, Hassali MA, Iqbal J, et al. Frequency and evaluation of the perceptions towards caesarean section among pregnant women attending public hospitals in Pakistan and the implications. Hosp Pract (1995). 2017;45(3):104-110.

https://doi.org/10.1080/21548331.2017.1328250

48. Jain $U$. The rates and indications of caesarean section in district hospital Shivpuri: A retrospective study from Madhya Pradesh. Int J Med Health Res. 2018;4(3):3.

49. Jawa A, Garg S, Tater A and Sharma U. Indications and rates of lower segment caesarean section at tertiary care hospitalan analytical study. Int J Reprod Contracept Obstet Gynecol. 2016;5:3466-3469.

50. Karim F, Ghazi A, Ali T, Aslam R, Afreen U and Farhat R. Trends and determinants of caesarean section. J Surg Pak. 2011;16(1):22-27.

51. Dayanada KR. Changing trend in indications of lower section caesarean section (LSCS) over a decade in a tertiary care Centre: An institutional study. J Radiol Case Rep. 2015;4(6):2080-2091.

52. Malla RV, Hamal C, Neupane B and Khatri R. Analysis of cesarean section using Robson's 10-group classification at a tertiary level hospital in Nepal. Med J Shree Birendra Hosp. 2018;17(2):4-11. https://doi.org/10.3126/mjsbh.v17i2.20290

53. Manjulatha $B$ and Sravanthi TP. Caesarean section rates in a teaching hospital: A ten year review. J Dent Med Sci. 2015;14(8):1-5.

54. Mehta AV, Patel IY, Dave VP and Gupta AV. Analysis of caesarean section rates according to Robson's ten group classification system and evaluating the indications within the groups (at a tertiary care hospital in West India). Int J Dent Med Sci Res. 2018;2(11):1-4.

55. Mittal S, Pardeshi S, Mayadeo N and Mane J. Trends in cesarean delivery: Rate and indications. J Obstet Gynaecol India. 2014;64(4):251-254.

https://doi.org/10.1007\%2Fs13224-013-0491-2

56. Nazneen R, Begum RA and Sultana K. Rising trend of caesarean section in a tertiary hospital over a decade. J Bangladesh Coll Physicians Surg. 2011;29(3):126-132. https://doi.org/10.3329/jbcps.v29i3.9432

57. Naeem M, Khan MZ, Abbas SH, Khan A, Adil M and Khan MU. Rate and indications of elective and emergency caesarean section; a study in a tertiary care hospital of Peshawar. JAMC. 2015;27(1):151-154.

58. Nikhil A. Analysis of trends in LSCS Rate and indications of LSCS-A study in a Medical College Hospital GMERS, Sola, Ahmedabad. Int J Pharm Biosci. 2015;2(1):1-5.

59. Pradhan B, Sharma $P$ and Bhandary S. Increasing trend of caesarean section in Patan Hospital. J Gen Pract Emerg Med Nepal. 2015;3(6):1-5.

60. Pradhan P, Shrestha S, Rajbhandari P and Dangal G. Profile of caesarean section in Kirtipur Hospital. Nepal J Obstet Gynaecol. 2014;9(2):51-54.

https://doi.org/10.3126/njog.v9i2.11763

61. Preetkamal $\mathrm{KH}$ and Nagpal M. Is current rising trend of cesarean sections justified. Int J Reprod Contracept Obstet Gynecol. 2017;6(3):872-876.

62. Samdal LJ, Steinsvik KR, Pun P, Dani P, Roald B, Stray-Pedersen $B$, et al. Indications for cesarean sections in Rural Nepal. J Obstet Gynecol India. 2016;66 Suppl 1:284-288. https://doi.org/10.1007\%2Fs13224-016-0890-2

63. Santhanalakshmi C, Gnanasekaran V and Chakravarthy AR. A retrospective analysis of cesarean section in a tertiary care hospital. Int J Sci Res. 2015;4(9):2097-2099.

64. Sarma P, Boro RC and Acharjee PS. An analysis of indications of caesarean sections at Tezpur medical college and hospital, Tezpur (a government hospital). Int J Reprod Contracept Obstet Gynecol. 2016;5(5):1364-1367.

65. Singh D, Regmi R, Gurung $T$ and Sunar L. Cesarean delivery and its indication: A cross sectional study in a tertiary care hospital, Pokhara, Nepal. NJOG. 2017;12(2):79-82.

66. Subedi S. Rising rate of cesarean section-a year review. J Nobel Med Coll. 2011;1(2):50-56. https://doi.org/10.3126/jonmc.v1i2.7303

67. Tahir N, Adil M, Fatima S and Khan S. Caesarian sections: Frequency and indications at peripheral tertiary care hospital. Pak Armed Forces Med J. 2018;68(2):273-279.

68. Jabeen J. Analysis of indications of caesarean sections. J Rawalpindi Med Coll. 2013;17(1):101-103.

69. Saxena N, Sharma B, Gupta V and Negi KS. Six year appraisal of caesarean delivery at a teaching hospital in Uttarakhand. Int J Reprod Contracept Obstet Gynecol. 2016;5(12):4369-4372. https://doi.org/10.18203/2320-1770.ijrcog20164345

70. Aminu M, Utz B, Halim A and van den Broek N. Reasons for performing a caesarean section in public hospitals in rural Bangladesh. BMC Pregnancy Childbirth. 2014;14(1):130. 
https://doi.org/10.1186/1471-2393-14-130

71. Rijal P. Identification of risk factors for cesarean delivery following induction of Labour. J Nepal Health Res Counc. 2014;12(27):73-77. https://doi.org/10.33314/jnhrc.v0i0.492

72. Baig JR, Jamal MM and Ashfaq T. A two year analysis of caesarean section delivery at $\mathrm{CMH}$ Hyderabad. Pak Armed Forces Med J. 2016;66(1):5.

73. Kim YM, Tappis H Zainullah P, Ansari N, Evans C, Bartlett L, et al. Quality of caesarean delivery services and documentation in first-line referral facilities in Afghanistan: A chart review. BMC Pregnancy Childbirth. 2012;12(1):14. https://doi.org/10.1186/1471-2393-12-14

74. Rafique $S$ and Raana G. Changing trends in caesarean section rate and indications. Pak J Surg. 2012;28(1):60-64.

75. Prasad A, Bhandari $G$ and Saha R. Profile of caesarean section at Kathmandu Medical College. J Nepal Health Res Counc. 2017; 15(2):111-113.

76. Islam MT and Yoshimura Y. Rate of cesarean delivery at hospitals providing emergency obstetric care in Bangladesh. Int J Gynaecol Obstet. 2015;128(1):40-43.

https://doi.org/10.1016/j.ijgo.2014.07.021

77. Amatya YR and Sapkota D. Patterns of delivery and perinatal outcomes among women delivered at district hospital of Rural Nepal. Online J Health Allied Sci. 2014;13(3):1.

78. Goonewardene M, Bhabu B, Chethiyawardhana I, Kalinga SS, Wickramasooriya J and Dandeniya R. Increasing caesarean section rates in a teaching hospital in Sri Lanka and the use of a modification of Robson ten group classification system for caesarean sections. Ginekol Pol Med Project. 2016;40:9-15.

79. Paudyal P, Gurung G, Baral J and Rana A. Changing trends in caesarean deliveries at a tertiary care Centra: $A$ ten year appraisal. J Soc Surg Nepal. 2014;17(2):7-11. https://doi.org/10.3126/jssn.v17i2.17141

80. Patil P, Bhardwaj M, Sharma $P$ and Chandrakar G. Changing trends in indication of cesarean section in a tertiary care Centre of Central India. Int J Reprod Contracept Obstet Gynecol. 2017;6(7):2829-2835.

81. Ajeet $S$ and Nandkishore $K$. The boom in unnecessary caesarean surgeries is Jeopardizing women's health. Health Care Women Int. 2013;34(6):513-521.

https://doi.org/10.1080/07399332.2012.721416

82. Jayanthi $P$ and Ratna G. Analysis of indications and complications of elective caesarean section in Primi at a tertiary care Centre, Vijayawada, Andhra Pradesh, India. J Evol Med Dent Sci. 2017;6(94):6849-6853.

83. Subhashini $R$ and Uma $N$. Changing trends in caesarean delivery. Int Arch Integr Med. 2015;2(3):96-102.

84. Jain $M$ and Patel $A$. A cross sectional study of rate, indications and complications of primary caesarean section. Int J Reprod Contracept Obstet Gynecol. 2016;5(6):1814-1819.

https://doi.org/10.18203/2320-1770.ijrcog20161668

85. Sultana R, Khatun M, Banu DS, Aktar MN, Ashraf R, Billah A, et al. Indications of emergency caesarean section at a Tertiary Care Hospital in Dhaka city. J Sci Found. 2017;15(2):36-40. https://doi.org/10.3329/jsf.v15i2.37780

86. Birla S, Gupta M, Birla P and Sharma J. Comparison of incidence, indication and complication of primary cesarean section in primigravida and multigravida. Int $\mathrm{J}$ Med Sci Educ. 2016;3(3):311-317.

87. Latif R, Rafique $\mathrm{S}$, Ashfaq M, Yasmeen $\mathrm{T}$, Javaid $\mathrm{S}$, Perveen $\mathrm{N}$, et al. An analysis of prevalence and indications of caesarean section in primigravida. Pak J Med Health Sci. 2017;11(1):9-11.
88. Karkee R, Lee AH, Khanal V, Pokharel PK and Binns CW. Obstetric complications and cesarean delivery in Nepal. Int J Gynaecol Obstet. 2014;125(1):33-36. https://doi.org/10.1016/j.ijgo.2013.09.033

89. Yadav RG and Maitra N. Examining cesarean delivery rates using the Robson's ten-group classification. J Obstet Gynecol India. 2016;66 Suppl 1:1-6.

https://doi.org/10.1007/s13224-015-0738-1

90. Neuman M, Alcock G, Azad K, Kuddus A, Osrin D, More NS, et al. Prevalence and determinants of caesarean section in private and public health facilities in underserved South Asian communities: Cross-sectional analysis of data from Bangladesh, India and Nepal. BMJ Open. 2014;4(12):e005982. https://doi.org/10.1136\%2Fbmjopen-2014-005982

91. Ali $\mathrm{Y}$, Khan MW, Mumtaz U, Salman A, Muhammad $\mathrm{N}$ and Sabir M. Identification of factors influencing the rise of cesarean sections rates in Pakistan, using MCDM. Int J Health Care Qual Assur. 2018;31(8):1058-1069.

https://doi.org/10.1108/ijhcqa-04-2018-0087

92. Hasan F, Sabiruzzaman MD, Joardar CK and Hossain MD. Maternal socio-demographic factors and nutritional status as predictors of caesarean delivery at hospitals in Rajshahi city, Bangladesh. Malays J Nutr. 2015;21(3):345-353.

93. Rahman M, Shariff AA, Shafie A, Saaid R and Tahir RM. Determinants of caesarean risk factor in Northern region of Bangladesh: A multivariate analysis. Iran J Public Health. 2014;43(1):16-27.

94. Khanal V, Karkee R, Lee AH and Binns CW. Adverse obstetric symptoms and rural-urban difference in cesarean delivery in Rupandehi district, Western Nepal: A cohort study. Reprod Health. 2016;13:17. https://doi.org/10.1186\%2Fs12978-016-0128-x

95. Maskey S, Bajracharya $M$ and Bhandari $S$. Prevalence of cesarean section and its indications in a Tertiary Care Hospital. J Nepal Med Assoc. 2019;57(216):70-73. https://doi.org/10.31729/jnma.4282

96. Shrestha $M$ and Shrestha $S$. Cesarean section profile at a tertiary center. NJOG. 2020;15(1):68-71. https://doi.org/10.3126/njog.v15i1.29345

97. Darnal $N$ and Dangal G. Maternal and fetal outcome in emergency versus elective caesarean section. J Nepal Health Res Counc. 2020;18(2):186-189. https://doi.org/10.33314/jnhrc.v18i2.2093

98. Patel BS, Patel AB, Patel AJ, Banker DA and Patel MB. Maternal and neonatal outcome in elective versus emergency cesarean section in a tertiary healthcare Centre in Ahmedabad, Western India. Br J Med Health Sci. 2020;2(5):231-240.

99. Shenoy H, Shenoy ST and Remash K. Determinants of primary vs previous caesarean delivery in a tertiary care institution in Kerala, India. Int J Clin Obstet Gynaecol. 2019;3(5):229-236. https://doi.org/10.33545/gynae.2019.v3.i5d.356

100. Pageni PR, Adhikari R, Dhungana PR and Kafle DR. Prevalence of caesarean section in Matri Shishu Miteri Hospital of Gandaki province. Med J Pokhara Acad Health Sci. 2020;3(1):244-248. https://doi.org/10.3126/mjpahs.v3i1.31925

101. Kanji Z, Simonovich SD, Najmi N and Bishop-Royse J. Examining clinical indications for cesarean section in a University Hospital in Karachi, Pakistan. J Asian Midwives. 2019;6(1):14-25.

102. Poudel R, Dangal G, Karki A, Pradhan HK, Shrestha R, Bhattachan $\mathrm{K}$, et al. Assessment of caesarean section rates at Kathmandu model hospital using the Robson's ten group classification system. J Nepal Health Res Counc. 2019;17(4):491-494. 
https://doi.org/10.33314/jnhrc.v17i4.2117

103. Shrestha A, Shrestha J and Gurung SD. Appraisal of caesarean section incidence and indications at Manipal teaching hospital, Pokhara, Nepal. Asian J Med Sci. 2021;12(1):50-54.

https://doi.org/10.3126/ajms.v12i1.30846

104. Wanyonyi $S$ and Muriithi FG. Vaginal birth after caesarean section in low resource settings: The clinical and ethical dilemma. J Obstet Gynaecol Can. 2015;37(10):922-926. https://doi.org/10.1016/S1701-2163(16)30031-7

105. Begum P, Saha DR and Zeba D. Indication and outcome of caesarean section in multigravid women with a history of vaginal delivery in a Tertiary Care Hospital. Faridpur Med Coll J. 2019;14(2):86-89.

106. Murphy DJ, Stirrat GM and Heron J. The relationship between caesarean section and subfertility in a population-based sample of 14541 pregnancies. Hum Reprod. 2002;17(7):1914-1917. https://doi.org/10.1093/humrep/17.7.1914

107. Janoudi G, Kelly S, Yasseen A, Hamam H, Moretti F and Walker M. Factors associated with increased rates of caesarean section in women of advanced maternal age. J Obstet Gynaecol Can. 2015;37(6):517-526.

https://doi.org/10.1016/S1701-2163(15)30228-0

108. Stjernholm YV, Petersson K and Eneroth E. Changed indications for cesarean sections. Acta Obstet Gynecol Scand. 2010;89(1):49-53.

https://doi.org/10.3109/00016340903418777

109. Akintayo AA, Ade-Ojo IP, Olagbuji BN, Akin-Akintayo OO, Ogundare OR and Olofinbiyi BA. Cesarean section on maternal request: The viewpoint of expectant women. Arch Gynecol Obstet. 2014;289(4):781-785.

https://doi.org/10.1007/s00404-013-3063-x

110. Schantz C, Sim KL, Petit V, Rany H and Goyet S. Factors associated with caesarean sections in Phnom Penh, Cambodia. Reprod Health Matters. 2016;24(48):111-121. https://doi.org/10.1016/j.rhm.2016.11.009

111. Christilaw JE. Cesarean section by choice: Constructing a reproductive rights framework for the debate. Int J Gynaecol Obstet. 2006;94(3):262-268.

https://doi.org/10.1016/j.ijgo.2006.04.006

112. Akhter S and Schech S. Choosing caesareans? The perceptions and experiences of childbirth among mothers from higher socioeconomic households in Dhaka. Health Care Women Int. 2018;39(11):1177-1192.

https://doi.org/10.1080/07399332.2018.1470181
113. Prakash KC and Neupane S. Cesarean deliveries among Nepalese mothers: Changes over time 2001-2011 and determinants. Arch Gynecol Obstet. 2014;289(2):421-427. https://doi.org/10.1007/s00404-013-2976-8

114. Rahman MM, Haider MR, Moinuddin M, Rahman AE, Ahmed S and Khan MM. Determinants of caesarean section in Bangladesh: Cross-sectional analysis of Bangladesh demographic and health survey 2014 data. PLoS One. 2018;13(9):e0202879. https://doi.org/10.1371/journal.pone.0202879

115. Amjad A, Amjad U, Zakar R, Usman A, Zakar MZ and Fischer F. Factors associated with caesarean deliveries among childbearing women in Pakistan: Secondary analysis of data from the demographic and health survey, 2012-13. BMC Pregnancy Childbirth. 2018;18(1):113. https://doi.org/10.1186\%2Fs12884-018-1743-z

116. Parvej Ml, Tabassum $\mathrm{M}$ and Aktar N. Preferences between caesarean section and normal vaginal delivery among the reproductive women in Bangladesh. J Appl Sci Eng Technol Educ. 2021;3(1):82-89. https://doi.org/10.35877/454RI.asci152

117. Begum T, Ellis C, Sarker M Rostoker JF, Rahman A, Anwar I, et al. A qualitative study to explore the attitudes of women and obstetricians towards caesarean delivery in rural Bangladesh. BMC Pregnancy Childbirth. 2018;18(1):368-368. https://doi.org/10.1186\%2Fs12884-018-1993-9

118. Doraiswamy S, Billah SM, Karim F, Siraj MS, Buckingham A and Kingdon C. Physician-patient communication in decision-making about caesarean sections in eight district hospitals in Bangladesh: A mixed-method study. Reprod Health. 2021;18(1):1-4. https://doi.org/10.21203/rs.3.rs-67631/v2

119. Karim F, Ali NB, Khan AN, Hasan MM, Hoque DM, Billah SM, et al. Prevalence and factors associated with caesarean section in four Hard-to-Reach areas of Bangladesh: Findings from a cross-sectional survey. PLoS One. 2020;15(6):e0234249. https://doi.org/10.1371/journal.pone.0234249

120. Murtaza K, Chaudhry M, Nazeer S and Malik S. Prevalencepattern and risk factors of cesarean section in a multiethnic cohort. Pak J Med Sci. 2021;37(3):711-715. https://doi.org/10.12669/pjms.37.3.3186

121. Peel A, Bhartia A, Spicer N and Gautham M. If I do 10-15 normal deliveries in a month I hardly ever sleep at home. A qualitative study of health providers' reasons for high rates of caesarean deliveries in private sector maternity care in Delhi, India. BMC Pregnancy Childbirth. 2018;18:470. https://doi.org/10.1186/s12884-018-2095-4

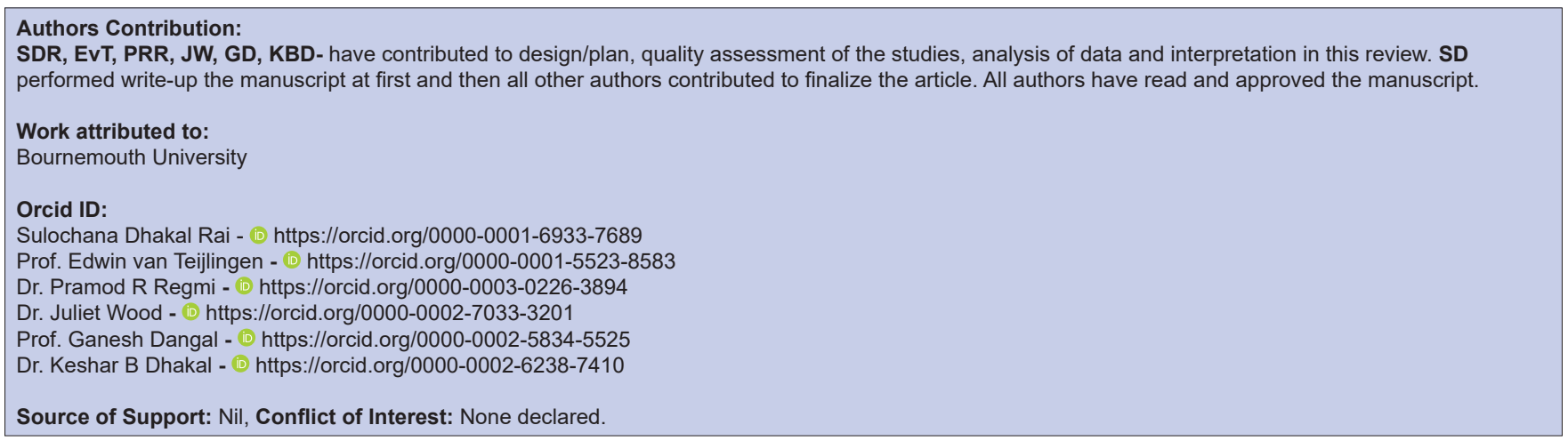




\section{SUPPLEMENTARY}

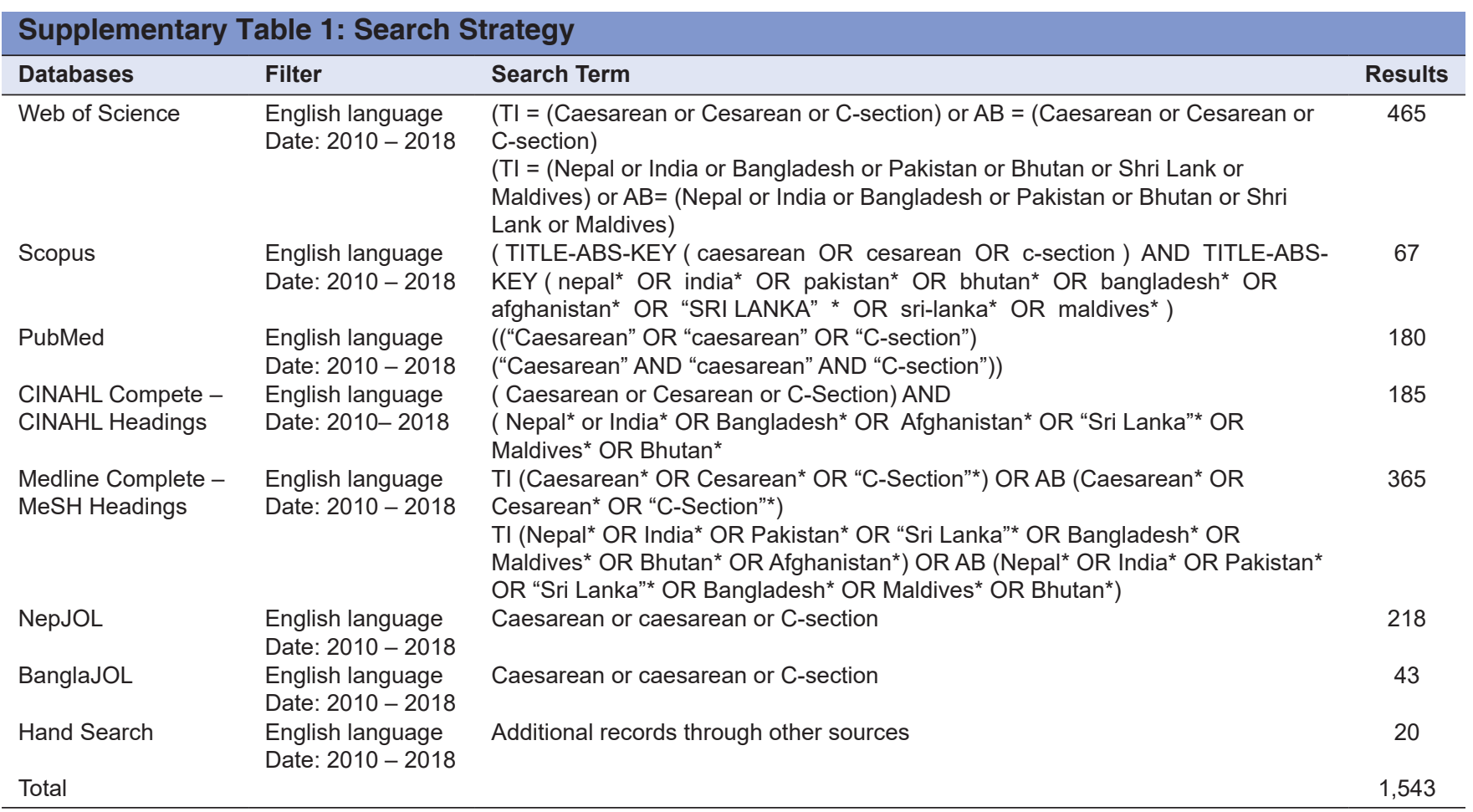




\section{Supplementary Table 2: Summary of indications of CS in South Asia}

\begin{tabular}{|c|c|c|c|c|c|}
\hline $\begin{array}{l}\text { Authors and } \\
\text { Year }\end{array}$ & $\begin{array}{c}\text { CS } \\
\text { rates }\end{array}$ & $\begin{array}{l}\text { Location } \\
\text { of study/ } \\
\text { Settings }\end{array}$ & Study design & $\begin{array}{l}\text { Study } \\
\text { population/ } \\
\text { Sample } \\
\text { size }\end{array}$ & Indications of CS \\
\hline $\begin{array}{l}\text { Nazneen et al., } \\
\text { (2011) }\end{array}$ & $70.5 \%$ & Bangladesh & $\begin{array}{l}\text { Retrospective } \\
\text { Observational }\end{array}$ & $\begin{array}{l}21149 \\
\text { Women }\end{array}$ & $\begin{array}{l}\text { Repeat C/S (17.2-31.4\%), Pre-eclampsia (7.3-21.7\%), } \\
\text { Foetal distress (6.5-17.9\%), Prolong labour }(2.2-6 \%) \text {, }\end{array}$ \\
\hline
\end{tabular}

(2011)

Aminu et al., (2014)

\section{$38.2 \% \quad$ Bangladesh}

Observational Longitudinal study

Foetal distress (6.5-17.9\%), Prolong labour (2.2-6\%),

Breech (1.7-8.1\%), Failed induction (1-6.7\%), Cervical dystocia (1-17.1\%), PROM (0.7-2.6\%), IUGR (1.5-4.1\%), Obstructed Labour (0.2-4.6\%), Eclampsia (0.3-1.6\%), APH (1-2.6\%), CPD (4.0-7.7\%), Postterm (1.2-3\%), Maternal choice (0.4-0.8\%)

Cross-sectional Mixed Method Study

530 Women

Cross-sectional Prospective Study

Cross-sectional Prospective study
100 Women

1253 Women

Ara et al., (2017) $\quad 78.7 \% \quad$ Bangladesh

Begum et al. (2017)
Retrospective Study Cross-sectional
2549 Women
Previous CS (29.4\%), Foetal distress (15.5\%), CPD (10.2\%), Prolonged labour/Obstructed labour (8.3\%), Post-term (7\%), HDP (4.5\%, Rupture of membrane (4.2\%), Breech (4\%), Fail Induction (3.6\%), Oligohydramnios (2.8\%),POH (2.5\%), Malpresentation (2.1\%), APH (1.1\%), Reduced foetal Movement (1.1\%), Unfavourable cervix $(0.9 \%)$, Multiple gestation $(0.6 \%)$, Maternal distress $(0.4 \%)$, Older primipara $(0.4 \%)$, Rhesus incompatibility $(0.2 \%)$, Anaemia $(0.2 \%)$, Recurrent UTI $(0.2 \%)$, Labour pain $(0.2 \%)$, No indication recorded $(0.6 \%)$ Elective CS: Previous CS (51.8\%), CPD (6.8\%),Post-term (4.1\%), HDP (4.5\%, Breech (3\%), Oligohydramnios (6\%), $\mathrm{POH}(7.3 \%)$, Malpresentation $(0.6 \%)$, Reduced foetal movement $(1.2 \%)$, Unfavourable cervix (1.2\%), Multiple gestation (1.2\%), Older primipara $(1.2 \%)$, Rhesus incompatibility $(0.6 \%)$, Recurrent UTI (0.6\%), No indication recorded (0.6\%) Emergency CS: Previous CS (19.2\%), Foetal distress (22.8\%), CPD (12.2\%), Prolonged labour/Obstructed labour (12.2\%), Post-term (2.5\%), HDP (5\%), Rupture of membrane $(6.1 \%)$, Breech $(4.2 \%)$, Fail Induction (5.3\%), Oligohydramnios $(2.5 \%), \mathrm{POH}(0.3 \%)$, Malpresentation (2.8\%), APH (1.7\%), Reduced foetal Movement (1.1\%), Unfavourable cervix (0.8\%), Multiple gestation $(0.3 \%)$, Maternal distress $(0.6 \%)$, Anaemia $(0.3 \%)$, Labour pain $(0.3 \%)$, Unfavourable cervix $(0.9 \%)$ Primary CS: Foetal distress, CPD, Post-term, Obstructed labour, Breech, Rupture of membrane, Fail induction Repeat CS: Previous CS

Primigravida: Post-term (19\%), CPD (9.3\%), Foetal distress (8.3\%)

Emergency CS: Previous caesarean section (25.0\%), Foetal distress (18.0\%), Obstructed labour (11.0\%), Placenta Previa $(7.0 \%)$, Abruptio Placentae $(1.0 \%)$, Preeclamptic toxaemia (7.0\%), Eclampsia (5.0\%), $\mathrm{PIH}(1.0 \%$ Malpresentation $(7.0 \%)$, Prolonged labour (6.0\%), CPD (4.0\%), Failed trial labour (4.0\%), Bad obstetric history $(2.0 \%)$, Cord prolapse $(1.0 \%)$, Diabetes Mellites (1.0\%) Previous CS (42.45\%), History of subfertility (4.99\%). HDP $(9.76 \%)$, Diabetes mellitus (4.31\%), Patient's desire $(3.97 \%), \mathrm{BOH}(2.61 \%)$, Prolonged labour and cervical dystocia $(7.7 \%)$, Post-dated pregnancy with oligohydramnios (5.6\%), Malpresentation (5.7\%),PROM and oligohydramnios (3.2\%), Foetal distress (5.1\%), Placenta praevia (1.5\%), Multiple pregnancy $(1.9 \%)$, APH $(1.3 \%)$

Elective CS: Previous caesarean section (55.7\%), History of subfertility (6.3\%), HDP $(12.4 \%)$,

Malpresentation (7.2\%), Diabetes mellitus (5.5\%), Patient's desire (5.1\%), Placenta praevia (1.9\%), $\mathrm{BOH}$ (3.3\%), Multiple pregnancy $(2.5 \%)$

Previous CS (24\%), Foetal distress (21\%), Prolonged labour and obstructed labour (16\%), Amniotic fluid disorder (14\%), Post-term (13\%), Malpresentation (3\%), HDP (3\%), Other (6\%) 


\begin{tabular}{|c|c|c|c|c|c|}
\hline $\begin{array}{l}\text { Authors and } \\
\text { Year }\end{array}$ & $\begin{array}{c}\text { CS } \\
\text { rates }\end{array}$ & $\begin{array}{l}\text { Location } \\
\text { of study/ } \\
\text { Settings }\end{array}$ & Study design & $\begin{array}{l}\text { Study } \\
\text { population/ } \\
\text { Sample } \\
\text { size }\end{array}$ & Indications of CS \\
\hline $\begin{array}{l}\text { Islam and } \\
\text { Yoshimura, } \\
(2015)\end{array}$ & $32 \%$ & Bangladesh & $\begin{array}{l}\text { Retrospective } \\
\text { Cross-sectional } \\
\text { Study }\end{array}$ & $\begin{array}{c}1075 \\
\text { Women }\end{array}$ & $\begin{array}{l}\text { Previous CS }(24.1 \%) \text {, Foetal distress }(21.9 \%) \text {, } \\
\text { Obstructed/prolonged labour (20.5\%), Post-term } \\
\text { (11.1\%), Oligohydramnios (6.1\%), Breech (3.7\%), } \\
\text { Pre-eclampsia and eclampsia (3.2\%), PROM/leaking } \\
(2.4 \%), \text { APH or placenta previa (1.4\%), No indication } \\
\text { recorded }(1.2 \%) \text {, Others }(4.3 \%)\end{array}$ \\
\hline $\begin{array}{l}\text { Das et al., } \\
(2018)\end{array}$ & $35.45 \%$ & India & $\begin{array}{l}\text { Retrospective } \\
\text { Cross-section } \\
\text { Study }\end{array}$ & $\begin{array}{c}1619 \\
\text { Women }\end{array}$ & $\begin{array}{l}\text { Foetal distress }(32.38 \%) \text {, Scar tenderness }(20 \%) \text {, } \\
\text { CPD }(15.74 \%) \text {, Previous CS } 1 \text { or more }(12.38 \%) \text {, } \\
\text { PIH }(2.85 \%) \text {, Refusal of vaginal delivery }(2.85 \%) \text {, } \\
\text { Oligohydramnios/IUGR }(2.38 \%) \text {, Breech }(2.38 \%) \text {, } \\
\text { Big baby-3.5 kg or more }(1.42 \%) \text {, Multifetal gestation } \\
(1.42 \%) \text {, } \\
\text { Malpresentation }(1.42 \%), \text { APH }(1.42 \%) \text {, Prematurity } \\
(1.42 \%) \text {, Medical disorder }(0.95 \%), \mathrm{BOH}(0.95 \%)\end{array}$ \\
\hline Jain U., (2018) & $17.49 \%$ & India & $\begin{array}{l}\text { Retrospective } \\
\text { Cross-sectional } \\
\text { Study }\end{array}$ & $\begin{array}{c}768 \\
\text { Women }\end{array}$ & 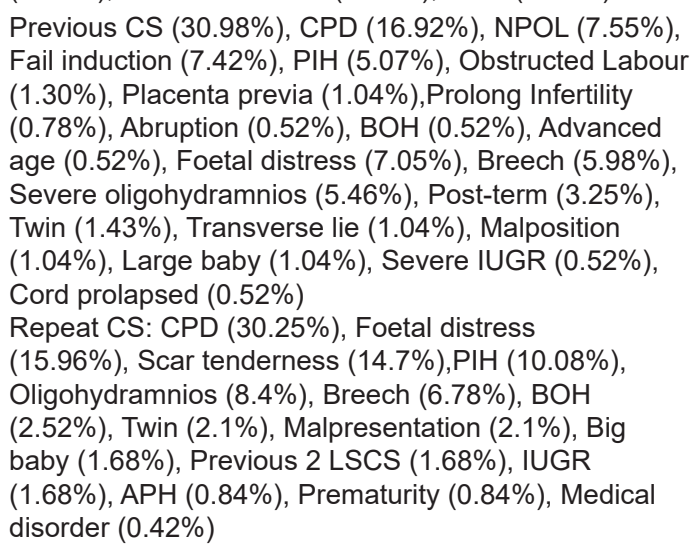 \\
\hline $\begin{array}{l}\text { Bade et al., } \\
(2014)\end{array}$ & $23.97 \%$ & India & $\begin{array}{l}\text { Retrospective } \\
\text { Cross-sectional } \\
\text { Study }\end{array}$ & $\begin{array}{c}2136 \\
\text { Women }\end{array}$ & $\begin{array}{l}\text { Previous CS }(24.8 \%) \text {, CPD (17.6\%), Failure to } \\
\text { progress }(16.6 \%) \text {, Threatened rupture }(20 \%), \text { HIVI } \\
\text { Genital lesion (1.2\%), APH (2.1\%), Obstructed labour } \\
\text { (3.1\%), Fail induction (2.1\%), Foetal distress (11.7\%), } \\
\text { Malpresentation (3.9\%), Multiple gestation }(2.9 \%) \text {, } \\
\text { Breech }(2.9 \%), \text { IUGR }(2.0 \%) \text {, Cord prolapsed }(1.2 \%) \text {, } \\
\text { Oligohydramnios }(2.0 \%) \text {, Other (3.1\%) }\end{array}$ \\
\hline $\begin{array}{l}\text { Subhashini R } \\
\text { and Uma N., } \\
(2015)\end{array}$ & $25.66 \%$ & India & $\begin{array}{l}\text { Retrospective } \\
\text { Cross-sectional } \\
\text { Study }\end{array}$ & $\begin{array}{c}8121 \\
\text { Women }\end{array}$ & 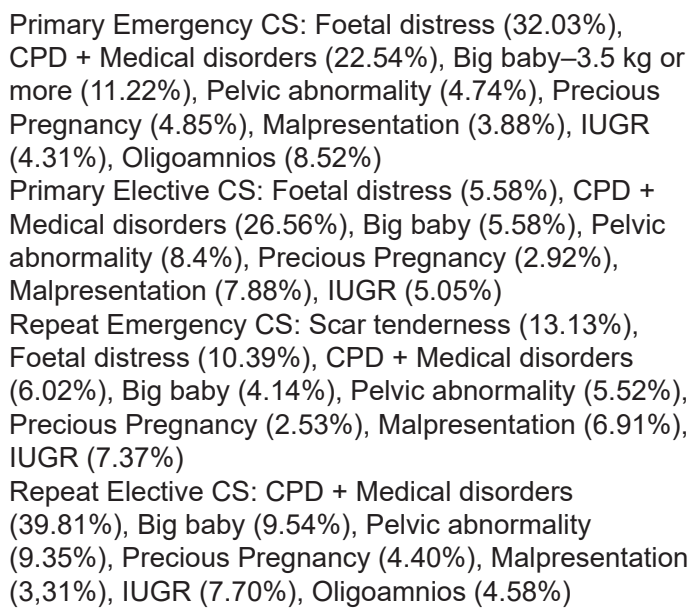 \\
\hline $\begin{array}{l}\text { Dayanand R. D., } \\
(2015)\end{array}$ & $25.7 \%$ & India & $\begin{array}{l}\text { Retrospective } \\
\text { Cross-sectional } \\
\text { Study }\end{array}$ & $\begin{array}{l}873 \\
\text { Women }\end{array}$ & $\begin{array}{l}\text { Previous CS } 1 \text { or mote }(45.77 \%) \text {, Foetal distress } \\
(14.97 \%), \text { PIH }(8.86 \%), \text { Malpresentation }(6.11 \%) \text {, } \\
\text { Failure of Induction }(5.06 \%) \text {, CPD }(4.64 \%), \text { Labour } \\
\text { abnormalities }(4.43 \%), \text { APH (3.53\%), Multiple } \\
\text { pregnancies }(2.11 \%) \text {, Oligohydramnios }(1.89 \%) \text {, } \\
\text { PROM }(1.89 \%), \text { IUGR }(0.63 \% \text {, Post-terms }(0.63 \%) \text {, } \\
\text { Medical disorders }(0.42 \%), \text { BOH }(1 \%) \text {, Cord prolapse } \\
(0.5 \%), \text { Hand prolapse }(0.25 \%)\end{array}$ \\
\hline
\end{tabular}




\begin{tabular}{|c|c|c|c|c|c|}
\hline $\begin{array}{l}\text { Authors and } \\
\text { Year }\end{array}$ & $\begin{array}{c}\text { CS } \\
\text { rates }\end{array}$ & $\begin{array}{l}\text { Location } \\
\text { of study/ } \\
\text { Settings }\end{array}$ & Study design & $\begin{array}{l}\text { Study } \\
\text { population/ } \\
\text { Sample } \\
\text { size }\end{array}$ & Indications of CS \\
\hline $\begin{array}{l}\text { Bala et al., } \\
(2017)\end{array}$ & $39.6 \%$ & India & $\begin{array}{l}\text { Retrospective } \\
\text { Cross-sectional } \\
\text { Study }\end{array}$ & $\begin{array}{c}11477 \\
\text { Women }\end{array}$ & 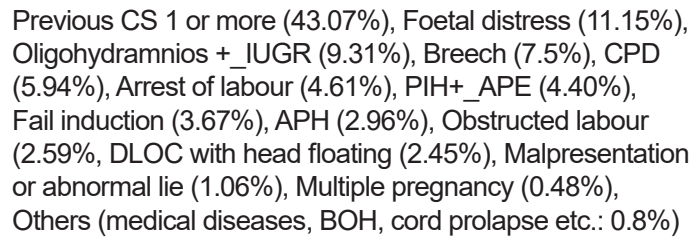 \\
\hline $\begin{array}{l}\text { Nikhill et al., } \\
\text { (2015) }\end{array}$ & $25.18 \%$ & India & $\begin{array}{l}\text { Retrospective } \\
\text { Cross-sectional } \\
\text { Study }\end{array}$ & $\begin{array}{c}1632 \\
\text { Women }\end{array}$ & 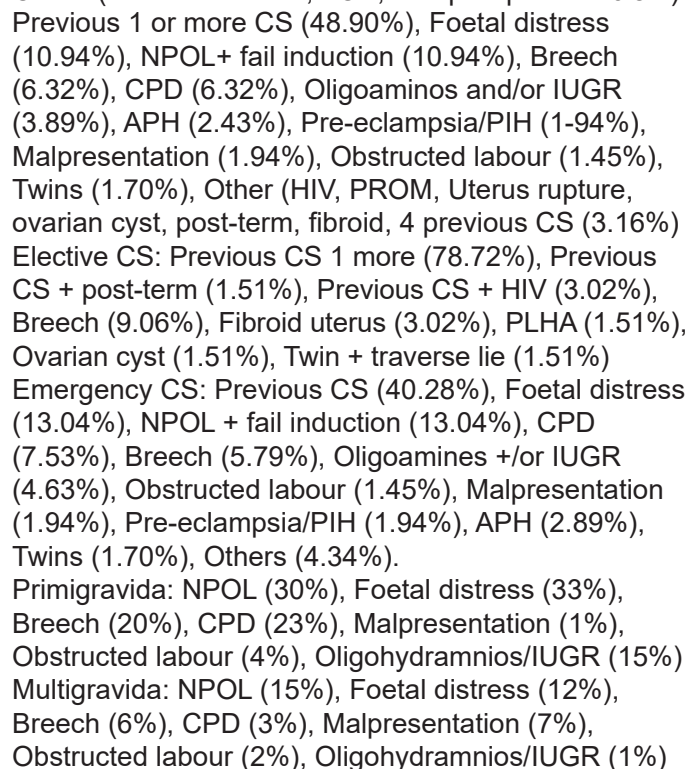 \\
\hline $\begin{array}{l}\text { Sarma et al., } \\
(2016)\end{array}$ & $27.60 \%$ & India & $\begin{array}{l}\text { Observational } \\
\text { Study }\end{array}$ & $\begin{array}{c}2278 \\
\text { Women }\end{array}$ & $\begin{array}{l}\text { Foetal distress }(30.99 \%) \text {, Repeat C/S }(23.00 \% \text {, } \\
\text { Induction failure }(14.00 \%) \text {, PIH }(12.99 \%) \text {, } \\
\text { Oligohydramnios }(5.0 \%) \text {, CPD }(2.02 \%) \text {, } \\
\text { Malpresentation ( } 3.03 \%) \text {, Obstructed labour }(2.94 \%) \text {, } \\
\text { APH }(2.02 \%) \text {, Prolonged labour (2.99\%), BOH }(1.01 \%)\end{array}$ \\
\hline $\begin{array}{l}\text { Patil et al., } \\
\text { (2017) }\end{array}$ & $48.18 \%$ & India & $\begin{array}{l}\text { Retrospective } \\
\text { Cross-sectional } \\
\text { Longitudinal } \\
\text { Study }\end{array}$ & $\begin{array}{l}1143 \\
\text { Women }\end{array}$ & 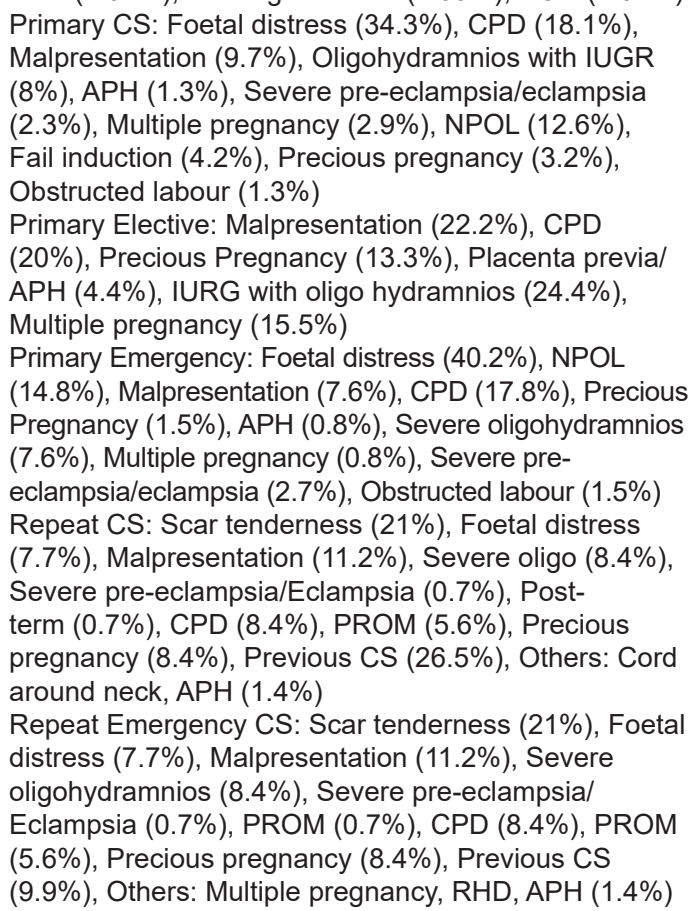 \\
\hline
\end{tabular}




\section{Supplementary Table 2: (Continued)}

\begin{tabular}{|c|c|c|c|c|c|}
\hline $\begin{array}{l}\text { Authors and } \\
\text { Year }\end{array}$ & $\begin{array}{c}\text { CS } \\
\text { rates }\end{array}$ & $\begin{array}{l}\text { Location } \\
\text { of study/ } \\
\text { Settings }\end{array}$ & Study design & $\begin{array}{c}\text { Study } \\
\text { population/ } \\
\text { Sample } \\
\text { size }\end{array}$ & Indications of CS \\
\hline
\end{tabular}

\begin{tabular}{|c|c|c|c|}
\hline $\begin{array}{l}\text { Desai et al., } \\
(2017)\end{array}$ & $\begin{array}{c}9.5 \% \\
\text { and } \\
15.6 \%\end{array}$ & India & $\begin{array}{l}\text { Retrospective } \\
\text { Cress-sectional } \\
\text { Longitudinal } \\
\text { Study }\end{array}$ \\
\hline
\end{tabular}

Repeat Elective CS: Post-term (1.6\%), Malpresentation

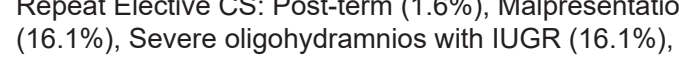
Severe pre-eclampsia/Eclampsia (1.6\%), CPD (16.1\%), Precious pregnancy $(9.7 \%)$, Previous CS (48.5\%), Others: Multiple pregnancy, RHD, APH (1.4\%)

Tribal mother: Foetal distress (31.2\%), Previous Caesarean sections (23.2\%), Prolonged Labour (11.2\%), Breech (16.0\%), Transverse lie $(5.2 \%)$, Obstructed Labour (2.5\%), Placenta previa (2.7\%), Multiple births (2.0\%), CPD (1.8\%), Placental abruption (1.3\%), Failed induction of labour (0.7\%), PIH (15.8\%), Eclampsia (4.8\%), Sickle Cell disease (2.8\%), Anaemia (5.8\%), Oligohydramnios (1.5\%), Other $(7.7 \%)$ Non-Tribal mother: Foetal distress (30.6\%), Previous Caesarean sections (12\%), Prolonged Labour (33.2\%), Breech (12,2\%), Transverse lie (2.8), Obstructed Labour $(1,7 \%)$, Placenta previa $(1,6 \%)$, Multiple births $(1,3 \%)$, CPD (1.2\%), Placental abruption (1.2\%), Failed induction of labour (0.7\%), PIH (15.4\%), Eclampsia (4.8\%), Anaemia (5.8\%), Oligohydramnios (1.5\%), Other $(8,4 \%)$

\begin{tabular}{|c|c|c|c|}
\hline $\begin{array}{l}\text { Birla et al., } \\
(2016)\end{array}$ & $31.61 \%$ & India & $\begin{array}{l}\text { Prospective } \\
\text { Cross-sectional } \\
\text { Study }\end{array}$ \\
\hline
\end{tabular}
Primary CS/Primigravida: Foetal distress (32.21\%), CPD (13.4\%), Breech (12.63\%), Failed progress (10.7\%), PIH (9.26\%), Obstructed labour (8.2\%), Oligohydramnios (6.53\%), IUGR (6.31\%), Failed induction (6.10\%), APE (4.42\%), Foetal hypoxia (3.16\%), PROM (2.10\%), Abruptio placenta (1.89\%), UPI (1.68\%), Precious pregnancy $(1.68 \%)$, DTA $(1.47 \%)$, Transverse lie $(1.26 \%)$, Brow presentation $(0.84 \%)$, Cord prolapse $(0.63 \%)$, Face presentation(0.21\%), Impending eclampsia (0.21\%) Primary CS/Multigravida: Foetal distress (17.45\%), CPD (13.82\%), Breech (10.18\%), Failed progress (8.73\%), PIH $(9.09 \%)$, Obstructed labour (6.54\%), Oligohydramnios (7.64\%), IUGR $(4.73 \%$,) Failed induction (3.64 \%), APE (Retrospective Longitudinal Study 0.73\%), Foetal hypoxia (2.18\%), PROM (4.73\%), Abruptio placenta (12.73\%), UPI (2.54 \%), Precious pregnancy $(0.73 \%)$, DTA $(0.73 \%)$, Transverse lie $(5.45 \%)$, Brow presentation $(1.09 \%)$, Cord prolapse $(1.45 \%)$, Face presentation (0.73\%), BOH (11.27\%), Placenta previa (8.73\%), Impending rupture $(0.73 \%)$, Vasa previa $(0.36 \%)$, Cord presentation (0.36\%, Medical indication (0.36\%)

\begin{tabular}{|c|c|c|c|}
\hline $\begin{array}{l}\text { Jain and Patel, } \\
(2016)\end{array}$ & $18.5 \%$ & India & $\begin{array}{l}\text { Retrospective } \\
\text { Cross-sectional } \\
\text { Study }\end{array}$ \\
\hline
\end{tabular}

Primary CS: Malpresentation (34.3\%), APH/placenta abruption/praevia (5.6\%), Non-reassuring foetal status $(8.2 \%)$, Severe oligohydramnios $(3.4 \%)$, Meconium stain liquor (22\%), Obstructed labour (3.9\%), NPOL $(4.1 \%)$, DTA $(0.7 \%)$, CPD $(0.9 \%$ Absent end diastolic flow $(0.4 \%)$, Failure of induction $(12.7 \%)$, Demand LSCS $(0.2 \%)$, Precious pregnancy in case of infertility $(0.7 \%)$, Cervical fibroid $(0.2 \%)$, Cervical dystocia $(0.2 \%)$, Generalized contracted pelvis $(2.6 \%)$

\begin{tabular}{|c|c|c|c|c|}
\hline $\begin{array}{l}\text { Jawa et al., } \\
(2016)\end{array}$ & $31.8 \%$ & India & $\begin{array}{l}\text { Retrospective } \\
\text { Cross-sectional } \\
\text { Study }\end{array}$ & $\begin{array}{c}1645 \\
\text { Women }\end{array}$ \\
\hline
\end{tabular}
Previous LSCS (23.90\%), Foetal distress (16.06\%), Breech (6.69\%), CPD (5.93\%), PIH (11.66\%), APH $(3.25 \%)$, Obstructed labour $(2.10 \%)$, Malpresentation $(2.68 \%)$, Multifetal gestation (2.10\%), Oligohydramnios/ IUGR $(5.93 \%)$,Cord prolapse $(0.96 \%)$, BOH $(1.53 \%)$, NPOL/failed induction (13.0\%), Medical disorders excluding $\operatorname{HDP}(4.21 \%)$ Emergency CS: Previous LSCS (18\%), Foetal distress (22\%), NPOL (18\%), Breech $(2.5 \%)$, CPD $(7 \%)$, HDP (14\%), APH (4.5\%), Obstructed labour (3\%), Malpresentation (2\%), Oligohydramnios/IUGR (6\%), Cord prolapse $(0.5 \%)$, $\mathrm{BOH}(1 \%)$ 


\begin{tabular}{|c|c|c|c|c|c|}
\hline $\begin{array}{l}\text { Authors and } \\
\text { Year }\end{array}$ & $\begin{array}{l}\text { CS } \\
\text { rates }\end{array}$ & $\begin{array}{l}\text { Location } \\
\text { of studyl } \\
\text { Settings }\end{array}$ & Study design & $\begin{array}{l}\text { Study } \\
\text { population/ } \\
\text { Sample } \\
\text { size }\end{array}$ & Indications of CS \\
\hline $\begin{array}{l}\text { Santhanalakshmi } \\
\text { et al., (2013) }\end{array}$ & $12.5 \%$ & India & $\begin{array}{l}\text { Retrospective } \\
\text { Cross-sectional } \\
\text { Study }\end{array}$ & $\begin{array}{c}530 \\
\text { Women }\end{array}$ & 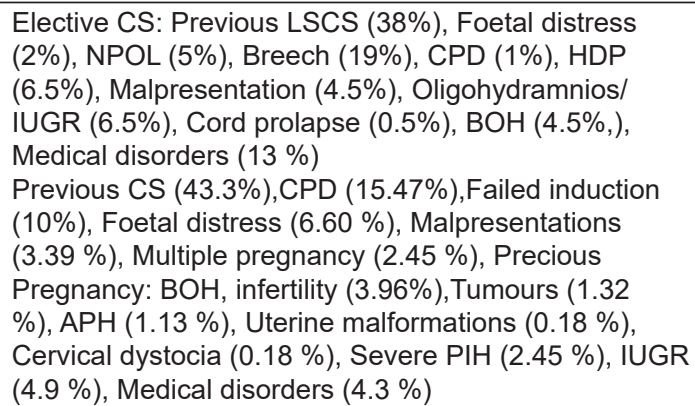 \\
\hline $\begin{array}{l}\text { Preetkamal and } \\
\text { Nagpal, (2017) }\end{array}$ & $33.2 \%$ & India & $\begin{array}{l}\text { Retrospective } \\
\text { Cross-sectional } \\
\text { Study }\end{array}$ & $\begin{array}{c}3233 \\
\text { Women }\end{array}$ & $\begin{array}{l}\text { Repeat CS }(29.9 \%) \text {, Placenta Previa }(3.9 \%) \text {, Abruptio } \\
\text { Placenta }(2.6 \%) \text {, NPOL }(5.4 \%) \text {, CPD }(5.3 \%) \text {, Pre- } \\
\text { Eclampsia }(3.7 \%) \text {, Eclampsia (1.3\%), Obstructed labour } \\
(0.7 \%) \text {, Fibroid }(0.7 \%) \text {, Foetal distress }(17.8 \%) \text {, Breech } \\
(16.8 \%) \text {, Transverse Lie } 1.3 \% \text {, IUGR }(3.9 \%) \text {, Severe } \\
\text { oligohydramnios (3.5\%), Twin pregnancy }(3.2 \%)\end{array}$ \\
\hline $\begin{array}{l}\text { Chavda et al., } \\
(2017)\end{array}$ & $19.9 \%$ & India & $\begin{array}{l}\text { Cross sectional } \\
\text { study }\end{array}$ & $\begin{array}{c}1000 \\
\text { Women }\end{array}$ & $\begin{array}{l}\text { Previous CS (39.9\%), Foetal distress }(19.1 \%) \text {, } \\
\text { Malpresentation (18.6\%), Failed induction }(7.3 \%) \text {, CPD } \\
(4.8 \%) \text {, Placenta previa (3.5\%), Severe Oligo hydramnios } \\
(2.0 \%) \text {, Obstructed labour (1.8\%), NPOL }(0.9 \%) \text {, Cord } \\
\text { prolapse }(0.8 \%) \text {, Precious pregnancy }(0.6 \%) \text {, Multifetal } \\
\text { gestations }(0.6 \%) \text {, Abruptio placenta }(0.2 \%)\end{array}$ \\
\hline $\begin{array}{l}\text { Dhodapkar } \\
\text { et al., (2015) }\end{array}$ & $32.6 \%$ & India & $\begin{array}{l}\text { Retrospective } \\
\text { Cross-sectional } \\
\text { Study }\end{array}$ & $\begin{array}{c}1123 \\
\text { Women }\end{array}$ & $\begin{array}{l}\text { Antepartum complication (31.2\%), CPD }(3.6 \%) \text {, } \\
\text { Contracted pelvis }(5.4 \%) \text {, Foetal distress }(1.3 \%) \text {, Not } \\
\text { willing for TOLAC }(22.4 \%) \text {, Previous } 2 \text { LSCS }(10.8 \%) \text {, } \\
\text { Scar tenderness }(2.2 \%) \text {, Unfavourable cervix }(2.0 \%)\end{array}$ \\
\hline $\begin{array}{l}\text { Saxena et al., } \\
(2016)\end{array}$ & $32.18 \%$ & India & $\begin{array}{l}\text { Retrospective } \\
\text { Cross-sectional } \\
\text { Study }\end{array}$ & $\begin{array}{c}2,707 \\
\text { Women }\end{array}$ & $\begin{array}{l}\text { Previous CS (33\%), Foetal distress (26.2\%), Breech } \\
\text { (8.8\%), Refusal of VBAC (7.5\%), Placenta previa } \\
\text { (5.8\%), NPOL (4.5\%), Unclear indications }(4.6 \%) \text {, } \\
\text { Multiple gestation (3.5\%), Failed induction (3.5\%), } \\
\text { Obstructed labour (3.3\%), IUGR/Abnormal Doppler } \\
(1.8 \%) \text {, Malpresentation (1.5\%), Scar tenderness } \\
(1.5 \%) \text {, CPD (1.5\%), Previous hysterotomy }(0.3 \%) \text {, } \\
\text { Oligohydramnios }(0.1 \%) \text {, Fibroid }(0.1 \%)\end{array}$ \\
\hline $\begin{array}{l}\text { Jayanthi and } \\
\text { Ratna, (2017) }\end{array}$ & $43 \%$ & India & $\begin{array}{l}\text { Prospective } \\
\text { Descriptive } \\
\text { Study }\end{array}$ & $\begin{array}{c}1929 \\
\text { Women }\end{array}$ & $\begin{array}{l}\text { Elective/Primigravida: Oligohydramnios (29.1\%), PIH } \\
(11.9 \%) \text {, Breech (19.17\%), CPD }(9.5 \% \text {, Short primi } \\
(7.6 \%) \text {, Transverse lie }(2.33 \%) \text {, Doppler changes } \\
(2.3 \%) \text {, Elderly primi }(2.3 \%), \text { Twins }(2.3 \%) \text {, Previous } \\
\text { abortions (1.91\%), GDM }(5.4 \%) \text {, Triplets }(0.4 \%), \text { IUGR } \\
\text { (3.3\%), Fibroid in LUS }(0.4 \%) \text {, Placenta previa }(0.4 \%) \text {, } \\
\text { Contracted pelvis }(0.4 \%), \text { Long marital life }(2.3 \%)\end{array}$ \\
\hline $\begin{array}{l}\text { Banerjee et al., } \\
(2018)\end{array}$ & $34.1 \%$ & India & $\begin{array}{l}\text { Retrospective } \\
\text { Cross-sectional } \\
\text { Study }\end{array}$ & $\begin{array}{l}75685 \\
\text { Women }\end{array}$ & $\begin{array}{l}\text { Foetal distress (32.8\%), Malpresentation }(7.33 \%) \text {, } \\
\text { Post caesarean pregnancy }(26.76 \%) \text {, Failed induction } \\
(3.67 \% \text {, Failed progression }(10.5 \%) \text {, CPD }(1.84 \%) \text {, } \\
\text { Multiple pregnancy }(2.7 \%) \text {, Maternal indication }(1.9 \%) \text {, } \\
\text { Obstetric indication }(8.2 \%) \text {, Foetal indication }(4.2 \%)\end{array}$ \\
\hline $\begin{array}{l}\text { Mehta et al., } \\
(2018)\end{array}$ & $41.92 \%$ & India & $\begin{array}{l}\text { Retrospective } \\
\text { Cross-sectional } \\
\text { Study }\end{array}$ & $\begin{array}{c}4785 \\
\text { Women }\end{array}$ & $\begin{array}{l}\text { Previous } 1 \text { CS with scar tenderness }(31.22 \%) \text {, } \\
\text { Previous } 2 \text { CS }(11.91 \%) \text {, Foetal distress }(20.74 \%) \text {, } \\
\text { NPOL }(9.34 \%) \text {, Breech }(4.67 \%) \text {, PIH/eclampsia } \\
(2.97 \% \text {, Obstructed labour }(3.08 \%) \text {, Severe } \\
\text { oligohydramnios/IUGR }(1.43 \%), \text { CPD }(9.45 \%) \text {, APH } \\
\text { (1.64\%), Multiple pregnancies }(2.05 \%) \text {, Abnormal lies/ } \\
\text { compound presentations (1.43\%), More than one } \\
\text { Indications }(3.03 \%)\end{array}$ \\
\hline $\begin{array}{l}\text { Mittal et al., } \\
(2014)\end{array}$ & $28,93 \%$ & India & $\begin{array}{l}\text { Retrospective } \\
\text { Cross-sectional } \\
\text { Study }\end{array}$ & $\begin{array}{l}19,990 \\
\text { Women }\end{array}$ & $\begin{array}{l}\text { Primary CS: Foetal distress }(11.06 \%) \text {, Arrest of } \\
\text { labour }(2.42 \%) \text {, Dilatation (1.68\%), Descent }(0.74 \%) \text {, } \\
\text { Malpresentation }(3.29 \%) \text {, Multiple gestation }(0.52 \%) \text {, } \\
\text { Obstetric indication }(1.45 \%) \text {, Maternal indication } \\
(0.17 \%) \text {, Foetal indication }(0.77 \%) \text {, CPD }(1.29 \%)\end{array}$ \\
\hline
\end{tabular}




\begin{tabular}{|c|c|c|c|c|c|}
\hline Supplemer & able & Contin & & & \\
\hline $\begin{array}{l}\text { Authors and } \\
\text { Year }\end{array}$ & $\begin{array}{c}\text { CS } \\
\text { rates }\end{array}$ & $\begin{array}{l}\text { Location } \\
\text { of study/ } \\
\text { Settings }\end{array}$ & Study design & $\begin{array}{l}\text { Study } \\
\text { population/ } \\
\text { Sample } \\
\text { size }\end{array}$ & Indications of CS \\
\hline
\end{tabular}

$\begin{array}{lccl}\begin{array}{l}\text { Ajeet and } \\ \text { Nandakishore, } \\ (2013)\end{array} & 40.8 \% & \text { India } & \begin{array}{l}\text { Cross-sectional } \\ \text { Study }\end{array} \\ \begin{array}{l}\text { Manjulatha } \\ \text { and Sravanthi, }\end{array} & 22.4 \% & \text { India } & \begin{array}{l}\text { Retrospective } \\ \text { (2015) }\end{array} \\ & & \begin{array}{l}\text { Cross-sectional } \\ \text { Longitudinal } \\ \text { Study }\end{array}\end{array}$

\section{Gupta and Garg, $\quad 31.46 \% \quad$ India} (2017) Study Study Study Study
Repeat CS: Foetal distress (18.67\%), Arrest of labour $(0.75 \%)$, Dilatation $(0.65 \%)$, Descent $(0.10 \%)$, Malpresentation (0.64 \%), Multiple gestation $(0.28 \%)$, Obstetric indication $(0.19 \%$, Maternal indication (0.04\%), Foetal indication (0. 23\%), CPD (1.63\%), C2 Caesarean section $(1.31 \%)$, Scar tenderness $(0.72 \%)$, Refusal of Vaginal Birth (0.23\%)

272 Elective CS: Post caesarean pregnancy, Cephalopelvic Women disproportion

Emergency CS: Foetal distress, Failure of progression of labour

Post caesarean pregnancy (9.69\%), Obstetric Indications (2.61\%: Placenta previa, abruptio placenta, placenta accrete, and cord prolapse), Failed Progression $(1.55 \%)$, Maternal Indications (1.14\%: Vesico-vaginal fistula repair, post myomectomy, complete perineal tear, and medical causes), Multiple gestation $(0.32 \%$, Foetal Indications (0.07\%: Intrauterine growth restriction, prematurity, and congenital malformations), Failed Induction (0.40\%), Malpresentation (1.98\%), CPD (2.66\%, Foetal Distress $(1.99 \%)$

Previous C-Section (36.52\%), Arrest of Labour Cross-sectional Women (13.65\%), CPD (12.03\%), Foetal Distress $(11.82 \%)$, Breech (7.52\%), Oligohydramnios/IUGR $(5.16 \%)$, Failed Induction (3.54\%), PIH 3.54\%, Obstructed labour $(2.90 \%)$, APH $(1.40 \%), \mathrm{BOH}(0.64 \%)$, Malpresentation (0.53\%), Multifetal gestation $(0.32 \%)$, Medical disorders excluding HDP $(0.21 \%)$, Cord prolapse $(0.11 \%)$, Prematurity $(0.11 \%)$

Repeat CS: Foetal distress (32.65\%), Scar tenderness (20.87\%), CPD (15.88\%), $\geq 2$ CS (12.65\%), PIH (3.24\%), Refusal of vaginal birth (3.24\%), Breech (2.94\%), Oligohydramnios/IUGR (2.94\%), Big baby $3.5 \mathrm{~kg}$ and more $(1.47 \%)$, Multifetal gestation $(1.18 \%)$, Malpresentation (0.88\%), APH (0.59\%), Prematurity $(0.59 \%)$, Medical disorders excluding HDP $(0.59 \%)$, $\mathrm{BOH}(0.29 \%)$

Prospective 11,964 Cross-sectional Women

Meconium stained liquor (22.7\%), Previous CS (15.6\%), Breech (12.1\%), Foetal distress $(10.7 \%)$, NPOL (16.5\%), CPD (5.3\%), Placenta previa (5\%), Abruptio placenta $(0.4 \%)$, Failed induction $(3.2 \%)$, Twin pregnancy $(2.1 \%)$, Pre-eclampsia $(2.1 \%)$, Eclampsia $(2.1 \%)$, Transverse lie $(1.9 \%)$, Obstructed labour $(1.2 \%)$, Cord prolapse $(0.9 \%)$, Deep transverse arrest $(1.3 \%)$, Bad obstetric history $(0.7 \%)$, Previous 2 CS $(0.9 \%)$, Others $(4.6 \%)$, On request $(0.3 \%)$

Retrospective $2011 \quad$ Foetal distress (6.25\%), Previous CS (21.25\%), Failed cross-sectional Women induction (11.25\%, NPOL (10\%), Breech $(10 \%)$, CPD

(4\%), Preeclampsia and eclampsia $(3.75 \%)$, APH (3.25\%), Severe Oligohydramnios (2.5\%), Multiple pregnancy $(2.5 \%)$, Obstructed labour (1.5\%), Uterine rupture $(1.25 \%)$, Cord prolapse $(1.25 \%)$, CS on Demand $(1.25 \%)$

Retrospective $\quad 1295 \quad$ Foetal distress (40.2\%), Previous CS (13.5\%), cross-sectional Women Oligohydramnios (8.9\%), NPOL (7.8\%), Failed induction $(5.9 \%)$, Breech (5.3\%), Cord round neck $(4.2 \%)$, CPD (2.8\%), PIH/preeclampsia (2.7\%), BOH (1.5\%), Malpresentation (2.8\%), APH (1.2\%), Maternal request $(1.0 \%)$, Intrahepatic cholestasis $(0.7 \%)$, Others $(1.45 \%)$ CPD (28\%), Foetal distress (25\%), Previous CS (14\%), Malpresentation (7\%), PROM (6\%), Preeclampsia (6\%), Failed induction (5\%), NPOL (5\%), BOH (2\%), Twins (1\%), APH (1\%) 


\begin{tabular}{|c|c|c|c|c|c|}
\hline $\begin{array}{l}\text { Authors and } \\
\text { Year }\end{array}$ & $\begin{array}{c}\mathrm{CS} \\
\text { rates }\end{array}$ & $\begin{array}{l}\text { Location } \\
\text { of studyl } \\
\text { Settings }\end{array}$ & Study design & $\begin{array}{l}\text { Study } \\
\text { population/ } \\
\text { Sample } \\
\text { size }\end{array}$ & Indications of CS \\
\hline $\begin{array}{l}\text { Acharya S. and } \\
\text { Raut B., (2017) }\end{array}$ & $17.34 \%$ & Nepal & $\begin{array}{l}\text { Retrospective } \\
\text { cross-sectional } \\
\text { Study }\end{array}$ & $\begin{array}{c}1367 \\
\text { Women }\end{array}$ & $\begin{array}{l}\text { Previous CS }(20.89 \%) \text {, NPOL (17.9\%), CPD }(16.2 \%) \text {, } \\
\text { Failed induction (15.7\%), Malpresentation (7.75\%), } \\
\text { Foetal distress }(5.1 \%) \text {, Severe oligohydramnious with } \\
\text { unfavourable cervix }(6.9 \%) \text {, Gestational hypertension } \\
\text { and eclampsia (4.4\%), Placenta previa and APH (1.8\%) }\end{array}$ \\
\hline $\begin{array}{l}\text { Dhakal et al., } \\
(2018)\end{array}$ & $18.8 \%$ & Nepal & $\begin{array}{l}\text { Retrospective } \\
\text { cross-sectional } \\
\text { Study }\end{array}$ & $\begin{array}{c}3,694 \\
\text { Women }\end{array}$ & $\begin{array}{l}\text { Foetal distress (20.1\%), Previous CS (17.8 \%), } \\
\text { Meconium stained liquor (17.7\%), NPOL (17.1\%), } \\
\text { Breech/malpresentation (15.8\%), Failed vacuum/ } \\
\text { instrumental }(2.3 \%) \text {, Obstructed labour }(2.2 \%) \text {, } \\
\text { Eclampsia }(2.0 \%) \text {, APH/placenta previa ( } 2 \%) \text {, Failed } \\
\text { induction (1.7\%), Oligohydramnios }(0.1 \%) \text {, Other (1.0\%) } \\
\text { Emergency CS: Foetal distress }(24.3 \%) \text {, Meconium } \\
\text { stained liquor (21.3\%), NPOL (20.6\%), Breech/ } \\
\text { malpresentation (13.3\%) } \\
\text { Elective CS: Previous CS (61.9\%), Breech/ } \\
\text { malpresentation }(28.0 \%)\end{array}$ \\
\hline $\begin{array}{l}\text { Singh et al., } \\
(2017)\end{array}$ & $25 \%$ & Nepal & $\begin{array}{l}\text { Retrospective } \\
\text { cross-sectional } \\
\text { Study }\end{array}$ & $\begin{array}{l}2250 \\
\text { Births }\end{array}$ & 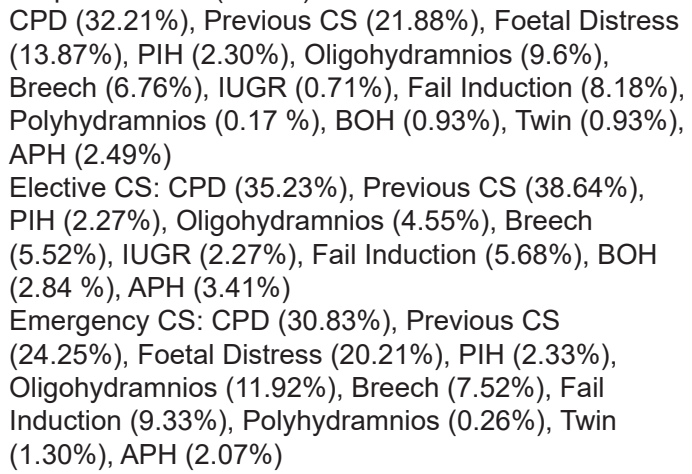 \\
\hline $\begin{array}{l}\text { Mall et al., } \\
(2018)\end{array}$ & $22.57 \%$ & Nepal & $\begin{array}{l}\text { Retrospective } \\
\text { Cross-sectional } \\
\text { Longitudinal } \\
\text { Study }\end{array}$ & $\begin{array}{c}4892 \\
\text { Women }\end{array}$ & $\begin{array}{l}\text { Previous CS }(28.7 \%) \text {, Foetal distress }(18.8 \%) \text {, } \\
\text { Abnormal presentation }(12.0 \%) \text {, CPD }(11.9 \%) \text {, } \\
\text { Oligohydramnios }(6.3 \%), \text { Fail induction }(5.1 \%) \text {, NPOL } \\
(4.2 \%), \text { PIH }(3.8 \%), \text { APH }(3.2 \%) \text {, IUGR }(2.6 \%) \text {, } \\
\text { Subfertility }(2.23 \%) \text {, Others }(7.4 \%)\end{array}$ \\
\hline $\begin{array}{l}\text { Poudyal et al., } \\
\text { (2014) }\end{array}$ & $39.23 \%$ & Nepal & $\begin{array}{l}\text { Retrospective } \\
\text { Cross-sectional } \\
\text { Longitudinal } \\
\text { Study }\end{array}$ & $\begin{array}{l}38,770 \\
\text { Women }\end{array}$ & $\begin{array}{l}\text { Emergency CS: Foetal distress ( } 41.9 \%) \text {, } \\
\text { Oligohydramnios }(9.69 \%) \text {, Previous CS }(5.57 \%) \text {, NPOL } \\
\text { ( } 5.45 \%) \text {, Failed induction }(4.03 \%) \\
\text { Elective CS: Previous CS }(9.4 \%) \text {, Breech }(1.9 \%) \text {, } \\
\text { Subfertility }(1.24 \%), \text { BOH }(1.21 \%) \text {, CPD }(0.98 \%)\end{array}$ \\
\hline $\begin{array}{l}\text { Bhandari B.R., } \\
(2015) 41\end{array}$ & $42.6 \%$ & Nepal & $\begin{array}{l}\text { Cross-sectional } \\
\text { Study }\end{array}$ & $\begin{array}{c}327 \\
\text { Women }\end{array}$ & $\begin{array}{l}\text { Foetal distress }(42.6 \%) \text {, Failed induction } \\
(15 \%) \text {, Abnormal presentation }(14.6 \%) \text {, Severe } \\
\text { oligohydramnios }(8 \%), \mathrm{BOH}(5 \%) \text {, NPOL }(5 \%), \mathrm{CPD} \\
(3.6 \%), \text { Prolonged second stage of labour }(3 \%), \mathrm{APH} \\
(2 \%) \text {, IUGR }(1.2 \%)\end{array}$ \\
\hline $\begin{array}{l}\text { Chaudhary et } \\
\text { al., (2018) }\end{array}$ & $63.27 \%$ & Nepal & $\begin{array}{l}\text { Retrospective } \\
\text { Cross-sectional } \\
\text { Study }\end{array}$ & $\begin{array}{c}275 \\
\text { Women }\end{array}$ & $\begin{array}{l}\text { Oligohydramnios ( } 41 \%) \text {, CPD }(34 \%), \text { NPOL }(29 \%) \text {, } \\
\text { Previous CS }(25 \%) \text {, Foetal distress }(21 \%) \text {, Breech } \\
(10 \%) \text {, Twins }(2 \%) \text {, APH }(2 \%) \text {, Triplets }(1 \%) \text {, Others }(9 \%)\end{array}$ \\
\hline $\begin{array}{l}\text { Prasad et al., } \\
(2017)\end{array}$ & $45.81 \%$ & Nepal & $\begin{array}{l}\text { Retrospective } \\
\text { Cross-sectional } \\
\text { Study }\end{array}$ & $\begin{array}{c}1172 \\
\text { Women }\end{array}$ & $\begin{array}{l}\text { Failed induction }(7.3 \%) \text {, Foetal distress }(19.55 \%) \text {, } \\
\text { Previous LSCS (11.5\%), Pervious LSCS with other risk } \\
\text { factors }(9.8 \%) \text {, CPD }(10.8 \%) \text {, Meconium stained liquor } \\
(9.6 \%) \text {, Breech/Malpresentation ( } 8.5 \%) \text {, HDP }(2.7 \%) \text {, } \\
\text { Oligohydramnios }(2.22 \%) \text {, Multiple pregnancy }(2.04 \%) \text {, } \\
\text { APH }(2 \%) \text {, NPOL }(0.7 \%) \text {, DTA }(0.3 \%) \text {, Others }(0.9 \%)\end{array}$ \\
\hline Rijal P., (2014) & - & Nepal & $\begin{array}{l}\text { Prospective } \\
\text { Observational } \\
\text { Study }\end{array}$ & $\begin{array}{c}348 \\
\text { Women }\end{array}$ & $\begin{array}{l}\text { Failed induction (24.7\%), Foetal distress }(46.0 \%) \\
\text { Meconium stained liquor (15.5\%), Dystocia }(13.8 \%)\end{array}$ \\
\hline $\begin{array}{l}\text { Amatya et al., } \\
(2013)\end{array}$ & $25.4 \%$ & Nepal & $\begin{array}{l}\text { Retrospective } \\
\text { Cross-sectional } \\
\text { Study }\end{array}$ & $\begin{array}{l}5907 \\
\text { Women }\end{array}$ & $\begin{array}{l}\text { Foetal distress (33.9\%), PROM (1.8\%), CPD (3.5\%), } \\
\text { Previous CS (14.7\%), Impending Eclampsia }(2.1 \%) \text {, } \\
\text { IUGR }(2.1 \%) \text {, NPOL ( } 6.7 \%) \text {, Failed induction }(4.2 \%) \text {, } \\
\text { Infertility (1.8\%), Primi breech (5.1\%), Oligoamines } \\
(7.5 \%), \text { PIH }(2.0 \%) \text {, DTA }(0.9 \%) \text {, Others }(13.5 \%)\end{array}$ \\
\hline
\end{tabular}




\section{Supplementary Table 2: (Continued)}

\begin{tabular}{|c|c|c|c|c|c|}
\hline $\begin{array}{l}\text { Authors and } \\
\text { Year }\end{array}$ & $\begin{array}{l}\text { CS } \\
\text { rates }\end{array}$ & $\begin{array}{l}\text { Location } \\
\text { of study/ } \\
\text { Settings }\end{array}$ & Study design & $\begin{array}{l}\text { Study } \\
\text { population/ } \\
\text { Sample } \\
\text { size }\end{array}$ & Indications of CS \\
\hline $\begin{array}{l}\text { Samdal et al., } \\
\text { (2016) }\end{array}$ & $9.5 \%$ & Nepal & $\begin{array}{l}\text { Cross-sectional } \\
\text { Prospective } \\
\text { Study }\end{array}$ & $\begin{array}{c}864 \\
\text { Women }\end{array}$ & 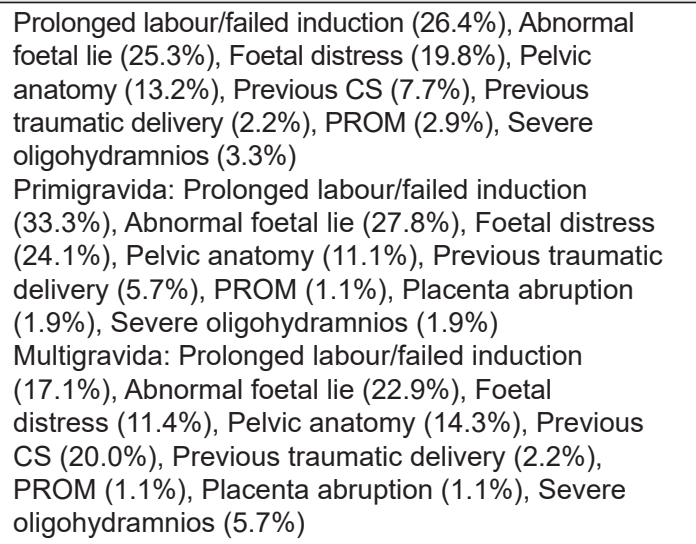 \\
\hline $\begin{array}{l}\text { Amatya YR } \\
\text { and Sapkota D, } \\
(2014)\end{array}$ & $18.5 \%$ & Nepal & $\begin{array}{l}\text { Retrospective } \\
\text { Cross-sectional } \\
\text { Study }\end{array}$ & $\begin{array}{c}369 \\
\text { Women }\end{array}$ & $\begin{array}{l}\text { Oligohydramnios (27.9\%), CPD (30.9\%), Placenta } \\
\text { Previa (1.5\%), NPOL (10.3\%), Failed induction }(2.9 \\
\%) \text {, Maternal distress (1.5\%), Previous CS }(2.9 \%) \text {, } \\
\text { PROM (1.5\%), Malpresentation/Malposition }(11.8 \%) \text {, } \\
\text { Meconium stained Liquor (32.4\%) } \\
\text { Elective CS: Oligohydramnios (26.5\%), CPD }(2.9 \%) \text {, } \\
\text { Failed induction (2.9\%), Previous CS (1.5\%), PROM } \\
\text { (1.5\%, Malpresentation/Malposition }(4.4 \%) \\
\text { Emergency CS: Oligohydramnios (1.5\%), CPD }(27.9 \%) \text {, } \\
\text { Placenta Previa (1.5\%), NPOL }(10.4 \%) \text {, Maternal } \\
\text { distress (1.5\%), Previous CS (1.5\%), Malpresentation/ } \\
\text { Malposition (7.5\%), Meconium stained Liquor (32.5\%) }\end{array}$ \\
\hline $\begin{array}{l}\text { Pradhan et al., } \\
\text { (2015) }\end{array}$ & $41.9 \%$ & Nepal & $\begin{array}{l}\text { Retrospective } \\
\text { Cross-sectional } \\
\text { Longitudinal } \\
\text { Study }\end{array}$ & $\begin{array}{c}44713 \\
\text { Women }\end{array}$ & $\begin{array}{l}\text { CPD (19.9\%), Previous CS (16.5\%), Foetal distress (14.3\%), } \\
\text { Meconium stained liquor (12.3\%), Failed induction }(9.8 \%) \text {, } \\
\text { NPOL ( } 8.9 \%) \text {, Breech (4.9\%), Severe oligohydramnios } \\
(4.5 \%) \text {, APH }(2.7 \%) \text {, Twin pregnancy }(1.9 \%)\end{array}$ \\
\hline $\begin{array}{l}\text { Latif et al., } \\
(2017)\end{array}$ & $81 \%$ & Pakistan & $\begin{array}{l}\text { Retrospective } \\
\text { Cross-sectional } \\
\text { Study }\end{array}$ & $\begin{array}{c}1354 \\
\text { Women }\end{array}$ & $\begin{array}{l}\text { Primigravida: Failure progression (31\%), Foetal } \\
\text { distress }(22 \%) \text {, Fail induction }(14 \%) \text {, Malpresentation } \\
(14 \%) \text {, PIH }(8.3 \%) \text {, Patients' request }(2.87 \%) \text {, } \\
\text { Chorioamnionitis }(2.1 \%) \text {, Precious pregnancy }(1.67 \%) \text {, } \\
\text { Obstructed Labour }(0.47 \%)\end{array}$ \\
\hline $\begin{array}{l}\text { Jabeen et al., } \\
\text { (2013) }\end{array}$ & $56 \%$ & Pakistan & $\begin{array}{l}\text { Cross-sectional } \\
\text { Study }\end{array}$ & $\begin{array}{c}3049 \\
\text { Women }\end{array}$ & $\begin{array}{l}\text { Previous scar }(40.37 \%) \text {, Failed induction }(13.58 \%) \text {, } \\
\text { Foetal distress }(11.23 \%) \text {, Malpresentation }(6.73 \%) \text {, } \\
\text { Failure to progress }(4.39 \%) \text {, CPD }(3.22 \%) \text {, } \\
\text { Polyhydramnios }(0.47 \%) \text {, Oligohydramnios }(4.68 \%) \text {, } \\
\text { PIH }(3.92 \%) \text {, IUD }(0.29 \%) \text {, Preterm }(0.70 \%), \text { APH } \\
(1.64 \%), \text { IUGR }(2.05 \%) \text {, Twins }(0.53 \%) \text {, Post-term } \\
(0.53 \%) \text {, Decreased Foetal movements }(0.99 \%) \text {, Poor } \\
\text { Bishop }(1.05 \%) \text {, PROM (0.76\%), BOH }(0.29 \%), \text { GDM } \\
(1.05 \%), \text { SROM }(0.29 \%) \text {, Precious pregnancy }(0.47 \%) \text {, } \\
\text { Unspecified }(0.76 \%)\end{array}$ \\
\hline $\begin{array}{l}\text { Karim et al., } \\
(2013)\end{array}$ & $27.94 \%$ & Pakistan & $\begin{array}{l}\text { Cross-sectional } \\
\text { Descriptive } \\
\text { Case Series } \\
\text { Method }\end{array}$ & $\begin{array}{l}778 \\
\text { Women }\end{array}$ & 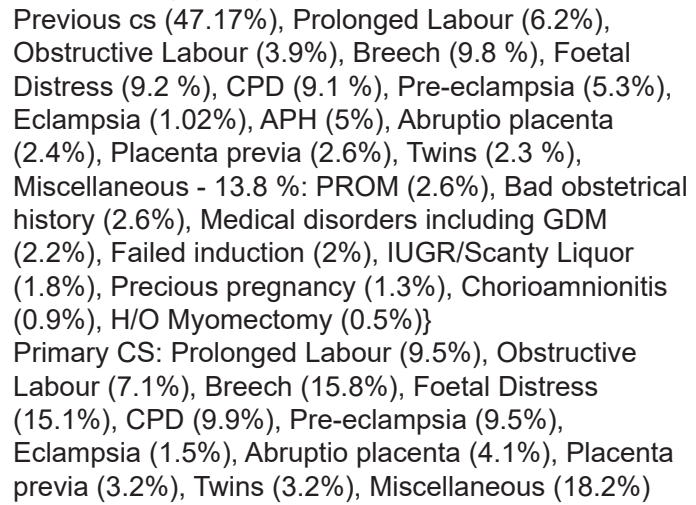 \\
\hline
\end{tabular}




\section{Supplementary Table 2: (Continued)}

\begin{tabular}{|c|c|c|c|c|c|}
\hline $\begin{array}{l}\text { Authors and } \\
\text { Year }\end{array}$ & $\begin{array}{l}\text { CS } \\
\text { rates }\end{array}$ & $\begin{array}{l}\text { Location } \\
\text { of study/ } \\
\text { Settings }\end{array}$ & Study design & $\begin{array}{c}\text { Study } \\
\text { population/ } \\
\text { Sample } \\
\text { size }\end{array}$ & Indications of CS \\
\hline
\end{tabular}

Repeat CS: Previous cs (47.17\%), Prolonged Labour (7.5\%), Obstructive Labour $(0.8 \%)$, Breech $(10 \%)$, Foetal Distress (8.3\%), CPD (25\%), Pre-eclampsia (1.7\%), Eclampsia (1.7\%), Abruptio placenta (1.7\%), Placenta previa (5,8\%), Twins (4.2\%), Miscellaneous Ehtisham et al., $\quad 44.8 \% \quad$ Pakistan
(2014)

Tahir et al., (2018)

Ishaq et al,, (2017)

Rafique and Raana, (2012)
Retrospective Cress-sectional Study

Cross-sectional $\quad 1,093$ Study

Women

Retrospective Cross-sectional Study

Retrospective Cross-sectional Study
1491 Women

Repeat Caesarean section (30.9\%), Previous scar in labour (5.7\%), Foetal distress (15.2\%), NPOL (13.9\%), Breech presentation (6.6\%), Pre-eclampsia/Eclampsia (3.9\%), Placental abruption (3.1\%), Placenta previa $(2.8 \%)$, Refusal of labour trial $(2.7 \%)$, IUGR $(2.4 \%)$, Good size baby (0.6\%), GDM/Uncontrolled Diabetes $(0.6 \%)$, Miscellaneous (11.5\%: Twins pregnancy $(1.49 \%)$, Precious pregnancy /BOH $-2.09 \%$, Scar tenderness $(1.57 \%)$, Decreased foetal movements $(1.2 \%)$, Patient wish (1.04\%), Maternal medical disorders $(2.1 \%)\left\{{ }^{*}\right.$ includes medical disorders like epilepsy, cardiac disease, Renal disease, liver disease, obstetric cholestatic and ITP\}, Foetal anomalies $-0.6 \%$ (includes diaphragmatic hernia, hydrocephalus), Fibroids/history of myomectomy $(0.4 \%)$, Perineal tear $(0.29 \%)$ Emergency CS: Repeat Caesarean section (1.04\%), Previous scar in labour (5.6\%), Foetal distress $(15.2 \%)$, NPOL (13.9\%), Breech (3.7\%), Preeclampsia/Eclampsia (3.2\%), Placental abruption (3.1\%), Placenta previa $(2.24 \%)$, Refusal of labour trial $(2.24 \%)$, IUGR $(1.04 \%)$, Good size baby $(0.14 \%)$, GDM/Uncontrolled Diabetes (0.14\%), Miscellaneous $(6.72 \%)$

Elective CS: Repeat Caesarean section (29.89\%), Breech (2.8\%), Pre-eclampsia/Eclampsia (0.59\%), Placenta previa $(0.59 \%)$, Refusal of labour trial $(0.44 \%)$, IUGR $(1.3 \%)$, Good size baby $(0.44 \%), \mathrm{GDM} /$ Uncontrolled Diabetes (0.44\%), Miscellaneous (4.7\%) Previous CS (59.4\%), Foetal distress $(26.9 \%)$, NPOL $(32.2 \%)$, Malpresentation (7.7\%), $\mathrm{PIH}(6.0 \%), \mathrm{BOH}$ $(2.2 \%)$, Abnormalities of placenta (1.8\%), GDM (1.2\%), Haemorrhagic disorders $(0.5 \%)$, Maternal request $(0.1 \%)$, Other $(0.5 \%)$

Primary CS: Foetal distress (60.8\%), NPOL (36.6\%), Malpresentation (14.1\%), PIH (8.2\%), BOH (4.0\%), Abnormalities of placenta (2.3\%), GDM (1.4\%), Haemorrhagic disorders $(0.9 \%)$, Maternal request $(0.2 \%)$, Other $(0.9 \%)$

1192 Previous CS (39.1\%), Obstructed labour (12.9\%), Long Women labour $(0.8 \%)$, Fail induction $(3.1 \%)$, Breech $(4.1 \%)$, Foetal distress $(2.4 \%)$, Cord prolapse $(1.4 \%)$, Others (36.2\%)

1115 Previous CS (56.3\%), Foetal distress (17.5\%); Failure Women to progress $(14.3 \%)$, malpresentation $(3.2 \%), \mathrm{PIH}$ $(3.2 \%)$, Placenta praevia $(2.93 \%)$, Placental abruption in $6(0.9 \%)$, Twin in $8(1.3 \%)$

Elective CS: Previous CS (23\%), malpresentation $(2.6 \%), \mathrm{PIH}(3.2 \%)$, Placenta praevia $(2.6 \%)$, Placental abruption $(2.6 \%)$, Twin in $8(0.98 \%)$

Emergency CS: Previous CS (33.2\%), Foetal distress $(17.5 \%)$; Failure to progress $(14.3 \%)$, malpresentation $(0.65 \%)$, PIH $(0.98 \%)$, Placenta praevia $(0.3 \%)$, Placental abruption in $6(0.98 \%)$, Twin $(0.3 \%)$ Previous CS $(30.51 \%)$, CPD and malpresentation $(20.14 \%)$, Failed progress of labour $(19.0 \%)$, Foetal distress (16.08\%), Eclampsia/Pre-eclampsia (7.22\%), $\mathrm{APH}(7.05 \%)$ 


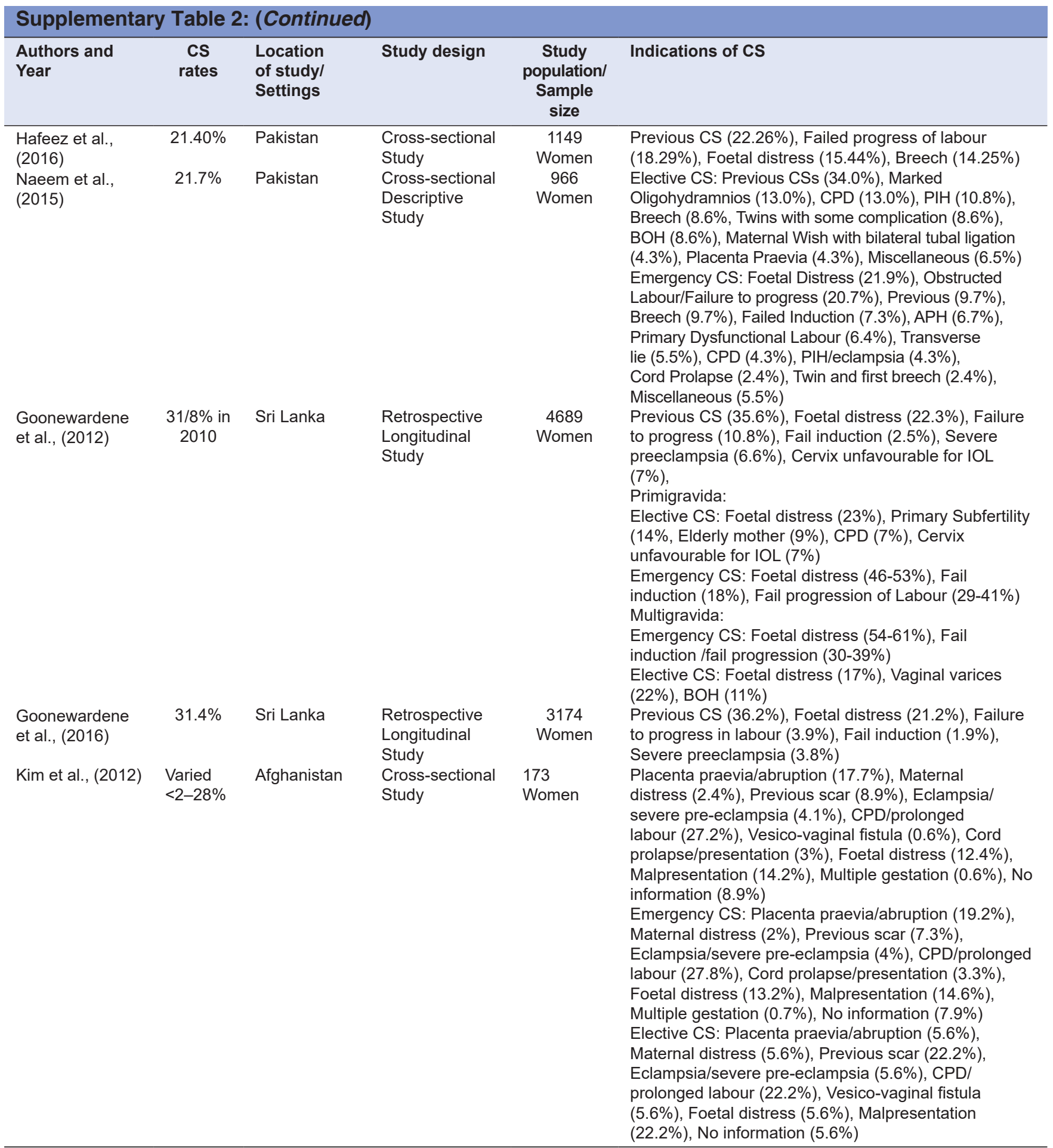




\begin{tabular}{|c|c|c|c|c|}
\hline $\begin{array}{l}\text { Authors and } \\
\text { Year }\end{array}$ & $\begin{array}{l}\text { Study } \\
\text { setting }\end{array}$ & $\begin{array}{l}\text { Study } \\
\text { design }\end{array}$ & Sample Size & $\begin{array}{l}\text { Major findings: Statistically significant factors associated with } \\
\text { rising CS rates }\end{array}$ \\
\hline $\begin{array}{l}\text { Khanal } \\
\text { et al., } 2016\end{array}$ & Nepal & $\begin{array}{l}\text { Community- } \\
\text { based } \\
\text { Cohort Study }\end{array}$ & $\begin{array}{l}735 \text { women } \\
\text { having an infant } \\
<1 \text { year }\end{array}$ & $\begin{array}{l}\text { Urban women (AOR: } 3.41,95 \% \mathrm{Cl} \text { : } 2.01-5.78 . \mathrm{P}<0.001) \\
\text { Women education secondary and above (AOR: } 2.56,95 \% \mathrm{Cl} \text { : } \\
\text { 1.28-5.14, <0.001) } \\
\text { Parity: Primiparous (AOR: } 1.85,95 \% \mathrm{Cl}: 1.16-2.95, \mathrm{P}<0.010 \text { ) }\end{array}$ \\
\hline $\begin{array}{l}\text { Karkee } \\
\text { et al., } 2014\end{array}$ & Nepal & $\begin{array}{l}\text { Prospective } \\
\text { Community- } \\
\text { based } \\
\text { Cohort }\end{array}$ & $\begin{array}{l}658 \text { women/ } \\
\text { births }\end{array}$ & $\begin{array}{l}\text { Higher age (OR: } 1.08,95 \% \mathrm{Cl}: 1.02-1.15, \mathrm{P}<0.004) \\
\text { Higher education: } \\
\text { - Primary (OR:1.65, 95\% Cl:0.52-5.21) } \\
\text { - Secondary (OR: } 2.12,95 \% \mathrm{Cl}: 0.70-6.3) \\
\text { - College (OR: } 3.43,95 \% \mathrm{Cl}: 1.17-10.07, \mathrm{P}<0.040) \\
\text { Residential location: Urban (OR: } 2.94,95 \% \mathrm{Cl}: 1.68-5.15, \mathrm{P}<0.001 \text { ) } \\
\text { Intrapartum complications (severe bleeding, prolong labour, swollen } \\
\text { hand/body etc.): Yes (OR: } 4.15,95 \% \mathrm{Cl}: 2.49-6.9, \mathrm{P}<0.001 \text { ) }\end{array}$ \\
\hline $\begin{array}{l}\text { Rijal et al., } \\
2014\end{array}$ & Nepal & $\begin{array}{l}\text { Hospital- } \\
\text { based } \\
\text { Prospective } \\
\text { Cohort Study }\end{array}$ & $\begin{array}{l}348 \text { pregnant } \\
\text { women induced } \\
\text { during labour }\end{array}$ & $\begin{array}{l}3 \text { doses of misoprostol (OR: } 6.027,95 \% \mathrm{Cl}: 1.832-19.839, \mathrm{P} 0.003) \\
\text { Prolonged latent phase of labour (OR: } 16.039,95 \% \mathrm{Cl}: 3.985- \\
64.551, \mathrm{P}<0.000) \\
\text { Prolonged active phase of labour (OR: } 9.627,95 \% \mathrm{Cl}: 3.914- \\
23.684, \mathrm{P}<0.000) \\
\text { Birth weight }<4 \mathrm{~kg} \text { (OR: } 4.384,95 \% \mathrm{Cl}: 1.702-11.109, \mathrm{P}<0.002) \\
\text { Bishop's score } 5 \text { or more (OR: } 1,95 \% \mathrm{Cl}: 0.13-0.816, \mathrm{P}<0.034)\end{array}$ \\
\hline $\begin{array}{l}\text { Neuman et al., } \\
2014\end{array}$ & $\begin{array}{l}\text { Bangladesh } \\
\text { (rural), India } \\
\text { (rural and } \\
\text { urban) and } \\
\text { Nepal Rural) }\end{array}$ & $\begin{array}{l}\text { Cross- } \\
\text { sectional } \\
\text { Study }\end{array}$ & $\begin{array}{l}45327 \text { births } \\
(21560 \text { in rural } \\
\text { Bangladesh, } \\
8541 \text { in rural } \\
\text { India, } 10236 \text { in } \\
\text { urban India and } \\
4931 \text { in rural } \\
\text { Nepal). }\end{array}$ & 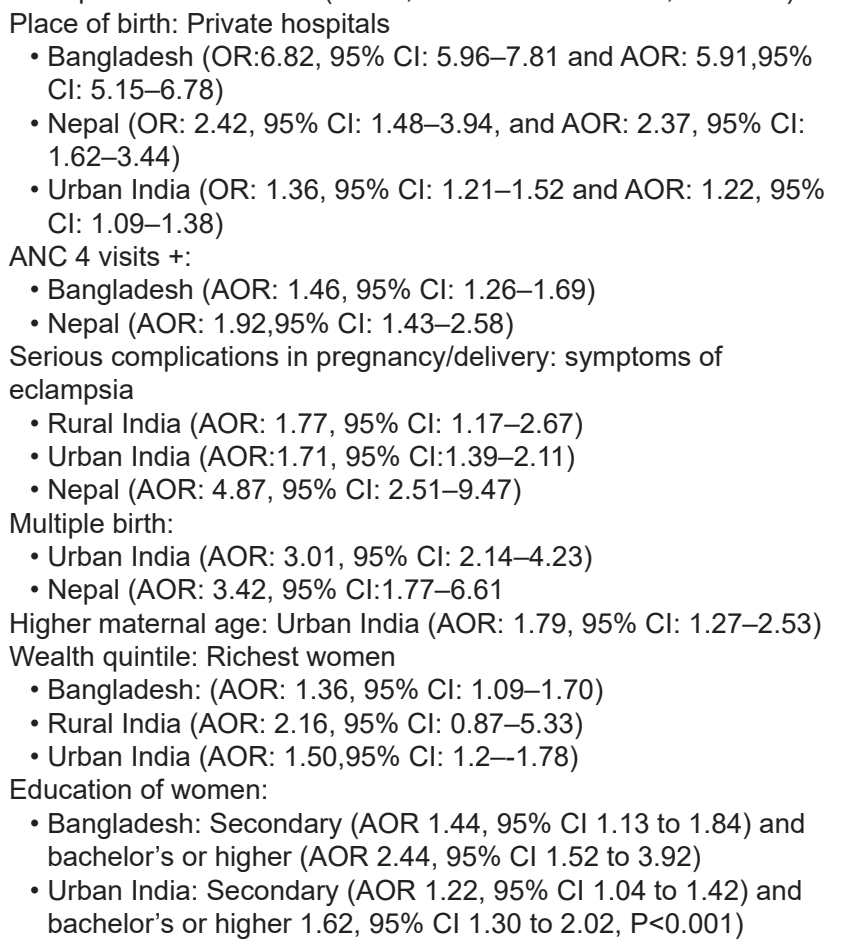 \\
\hline $\begin{array}{l}\text { Desai } \\
\text { et al., } 2017\end{array}$ & India & $\begin{array}{l}\text { Cross- } \\
\text { sectional } \\
\text { Longitudinal } \\
\text { Study }\end{array}$ & 19923 births & $\begin{array}{l}\text { Higher age of women: } \\
\text { - Tribal mother: } 25-29 \text { (AOR: } 1.9,95 \% \mathrm{Cl}: 1.40-2.8, \mathrm{P}<0.000), 30 \\
\text { and above (AOR: } 3.32,95 \% \mathrm{Cl}: 2.19-5.03, \mathrm{P}<0.000) \\
\text { Higher education: } \\
\text { - Non-tribal women: } 8-12 \text { years (AOR: } 1.45,95 \% \mathrm{Cl}: 1.07-1.98 \text {, } \\
\mathrm{P}<0.018 \text { ), } 12 \text { years and more (AOR: } 0.73,95 \% \mathrm{Cl}: 0.54-0.98 \text {, } \\
\text { P<0.039) } \\
\text { Low Parity: Primiparous Tribal women and Non-tribal women ( } \mathrm{P}< \\
0.000 \text { ) } \\
\text { History of previous CS: } \\
\text { - Tribal women (AOR: } 44.7,95 \% \mathrm{Cl}: 34.74-57.51, \mathrm{P}<0.000 \text { ) and } \\
\text { Non-tribal (AOR: } 57.51,95 \% \mathrm{Cl}: 41.97-78.82, \mathrm{P}<0.00) \text {. } \\
\text { ANC visits } 3 \text { or more: } \\
\text { - Non-tribal (AOR: } 1.67,95 \% \mathrm{Cl}: 1.16-2.41, \mathrm{P}<0.006) \\
\text { Distance from the health facility } 26-50 \mathrm{Kil} \text { ) } \\
\text { - Tribal (AOR: } 1.31,95 \% \mathrm{Cl}: 1.07-1.59, \mathrm{P}<0.007 \text { ) }\end{array}$ \\
\hline
\end{tabular}




\section{Supplementary Table 3: (Continued)}

\begin{tabular}{|c|c|c|c|c|}
\hline $\begin{array}{l}\text { Authors and } \\
\text { Year }\end{array}$ & $\begin{array}{l}\text { Study } \\
\text { setting }\end{array}$ & $\begin{array}{l}\text { Study } \\
\text { design }\end{array}$ & Sample Size & $\begin{array}{l}\text { Major findings: Statistically significant factors associated with } \\
\text { rising CS rates }\end{array}$ \\
\hline $\begin{array}{l}\text { Begum et al., } \\
2017\end{array}$ & Bangladesh & $\begin{array}{l}\text { Retrospective } \\
\text { Cross- } \\
\text { sectional } \\
\text { Study }\end{array}$ & 2549 Births & $\begin{array}{l}\text { Higher age of mother: } \\
\text { - } 30-34 \text { years (AOR: } 2.15,95 \% \mathrm{Cl}: 1.48-3.29, \mathrm{P}<0.005) \text { and } 35 \\
\text { years or more (AOR: } 2.00,95 \% \mathrm{Cl}: 1.18-3.40, \mathrm{P}<0.005) \\
\text { Higher education: } \\
\text { - Higher secondary and above (AOR: } 2.06,95 \% \mathrm{Cl}: 1.24-3.25 \text {, } \\
\text { P<0.005) } \\
\text { Birth order: } \\
\text { • } 1 \text { (AOR:1), } 2 \text { (AOR: } 0.56,95 \% \mathrm{Cl}: 0.46-0.76, \mathrm{P}<0.005) \text { and } 3 \text { or } \\
\text { more (AOR:0.32, 95\% Cl: } 0.23-0.44, \mathrm{P}<0.005) \\
\text { Wealth Quintiles: } \\
\text { - Rich (AOR: } 1.90,95 \% \mathrm{Cl}: 1.37-2.58, \mathrm{P}<0.005) \text { and Richest } \\
\text { (AOR: } 2.47,95 \% \mathrm{Cl}: 1.78-3.34, \mathrm{P}<0.005) \\
\text { Number of ANC visits: } \\
\text { • } 3 \text { (AOR:1.40, } 95 \% \mathrm{Cl}: 1.11-1.76, \mathrm{P}<0.005) \text { and }>3 \text { (AOR: } 2.19 \text {, } \\
\quad 95 \% \mathrm{Cl}: 1.67-2.82, \mathrm{P}<0.005)\end{array}$ \\
\hline
\end{tabular}

\begin{tabular}{|c|c|c|c|}
\hline $\begin{array}{l}\text { Ajeet and } \\
\text { Nandkishore, } \\
2013\end{array}$ & India & $\begin{array}{l}\text { Cross- } \\
\text { sectional } \\
\text { Study } \\
\text { House } \\
\text { to house } \\
\text { survey }\end{array}$ & $\begin{array}{l}272 \text { Women who } \\
\text { had a child under } \\
\text { five years }\end{array}$ \\
\hline $\begin{array}{l}\text { Yadav et al., } \\
2015\end{array}$ & India & $\begin{array}{l}\text { Cross- } \\
\text { sectional } \\
\text { Longitudinal } \\
\text { Study }\end{array}$ & 40,086 births \\
\hline Ali et al., 2018 & Pakistan & $\begin{array}{l}\text { Questionnaire } \\
\text { Survey using } \\
\text { DEMATEL } \\
\text { method }\end{array}$ & $\begin{array}{l}\text { Gynaecologists } \\
\text { working in either } \\
\text { public or private } \\
\text { hospitals }\end{array}$ \\
\hline
\end{tabular}

History of foetal loss (AOR: 1.38, 95\% Cl: 1.10-1.73, $\mathrm{P}<0.005)$

Place of delivery: Private/nursing home (AOR: $2.73,95 \% \mathrm{Cl}$ :

1.51-4.94, $P<0.05)$

Pregnancy duration: Pre/post-term (AOR: 1.85, 95\% Cl: 1.01-3.39,

$\mathrm{P}<0.05)$

Socioeconomic status: Rich (Class I, II, and III) (AOR: 2 .53, 95\%

$\mathrm{Cl}: 1.45-4.40, \mathrm{P}<0.05)$

Birth weight $>4 \mathrm{Kg}$ (Coefficient: - $-0.09257, \mathrm{P}<0.0001)$

Abnormal foetal presentation (Coefficient: 0.7302, $\mathrm{P}<0.0001)$

Increasing gestational age (>37 weeks) (Coefficient: -0.4523 ,

$P<0.001)$

Increasing maternal age (>35 years) (Coefficient: 0.01187,

$\mathrm{P}<0.0001)$

Parity: Nulliparous (Coefficient: $-0.1158, \mathrm{P}<0.0001$ )

Medical factors:

- Obesity (Matrices value: $\mathrm{ri}+\mathrm{ci}=-45.35909106, \mathrm{ri}-\mathrm{ci}=$ 1.748565604)

- Age of mother (Matrices value: $\mathrm{ri}+\mathrm{ci}=-31.8434601$, ri-ci $=$ 2.172376183)

- Umbilical cord prolapse (Matrices value: $\mathrm{ri}+\mathrm{ci}=-31.54166732$, ri-ci $=0.630270284$ )

Non-medical factors:

- Patient's preference towards CS (Matrices value: $\mathrm{ri}+\mathrm{ci}=$ 85.76431003, ri-ci = 7.654406112)

- Increasing number of private hospitals (Matrices value: $\mathrm{ri}+\mathrm{ci}=$ 86.36295414, ri-ci = 7.836383342)

- The poor condition of public hospitals (Matrices value: $\mathrm{ri}+\mathrm{ci}=$ 78.90532342, ri-ci $=0.32802823$ )

- The unavailability of good quality health care and hospital in rural areas (Matrices value: $\mathrm{ri}+\mathrm{ci}=77.82678084$, $\mathrm{ri}-\mathrm{ci}=0.709594802$ )

Hasan et al., Bangladesh Cross- 194 Women 2015 sectional

Study interviewed within 24-48 h after giving birth
Overweight of mother $(\mathrm{P}<0.01)$; underweight $(\mathrm{OR}: 0.021,95 \% \mathrm{Cl}$ : $0.002-0.196, P<0.01$ ) and normal weight women (OR: $0.048,95 \%$ Cl: $0.013-0.176, \mathrm{P}<0.01)$

Higher age of mother: 25 year and above $(P<0.01) ; 15-20$ years (OR: $0.050,95 \% \mathrm{Cl}: 0.010-0.248, \mathrm{P}<0.01)$ and $20-25$ years (OR: $0.140,95 \% \mathrm{Cl}: 0.410-0.479)$.

Higher education of mother's education $(\mathrm{P}<0.05)$; primary educated women (OR: 0.192, 95\% Cl: 0.045-0.818, $\mathrm{P}<0.05)$.

Using contraceptive method $(\mathrm{P}<0.01)$; Women using contraceptive Devices (OR: $0.229,95 \% \mathrm{Cl}: 0.076-0.687, \mathrm{P}<0.01$ )

History of previous CS ( $\mathrm{P}<0.01)$; Women who did not have history of CS (OR: 0.008, 95\% Cl: 0.023-0.414, $\mathrm{P}<0.01$ ).

- Mother's weight: Underweight (OR: 0.021, 95\% Cl: 0.002-0.196, $\mathrm{P}<0.01)$ and normal weight women (OR: $0.048,95 \% \mathrm{Cl}: 0.013-0.176$, $\mathrm{P}<0.01)$ were very less likely having a CS than overweight women.

- Previous CS: Women who did not have history of CS (OR: 0.008, 95\% Cl: 0.023-0.414, P<0.01) were very less chances having a CS than women who had a previous CS. 


\begin{tabular}{|c|c|c|c|c|}
\hline \multicolumn{5}{|c|}{ Supplementary Table 3: (Continued) } \\
\hline $\begin{array}{l}\text { Authors and } \\
\text { Year }\end{array}$ & $\begin{array}{l}\text { Study } \\
\text { setting }\end{array}$ & $\begin{array}{l}\text { Study } \\
\text { design }\end{array}$ & Sample Size & $\begin{array}{l}\text { Major findings: Statistically significant factors associated with } \\
\text { rising CS rates }\end{array}$ \\
\hline $\begin{array}{l}\text { Rahman et al., } \\
2014\end{array}$ & Bangladesh & $\begin{array}{l}\text { Cross- } \\
\text { sectional } \\
\text { Study } \\
\text { Interview }\end{array}$ & $\begin{array}{l}1142 \text { women } \\
\text { admitted in } \\
\text { hospitals for } \\
\text { giving birth }\end{array}$ & 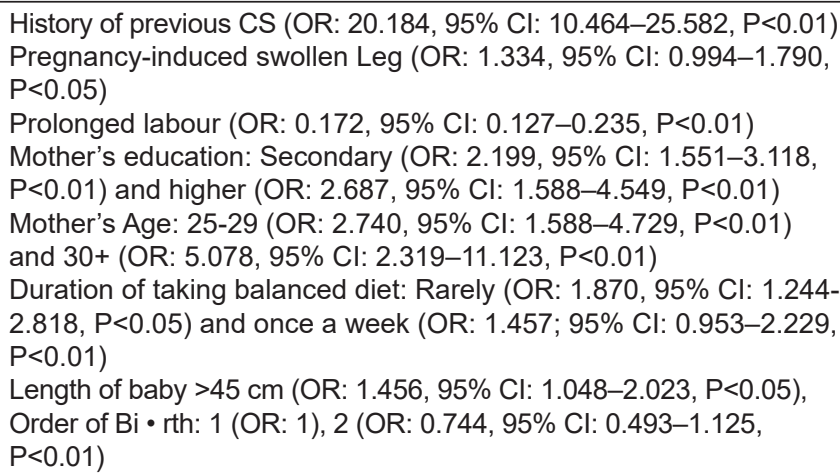 \\
\hline
\end{tabular}

\begin{tabular}{|c|c|c|c|c|c|c|c|c|c|c|c|c|c|}
\hline Studies & Q1 & Q2 & Q3 & Q4 & Q5 & Q6 & Q7 & Q8 & Q9 & Q10 & Q11 & Q12 & Total score \\
\hline Acharya et al., $2017^{27}$ & 3 & 3 & 3 & 3 & 3 & NA & 3 & 3 & 3 & 3 & 3 & 3 & 33 \\
\hline Amatya et al., $2013^{28}$ & 3 & 3 & 3 & 3 & 3 & NA & 3 & 3 & 3 & 3 & 3 & 3 & 33 \\
\hline Ara et al., $2018^{29}$ & 3 & 3 & 3 & 3 & 3 & NA & 3 & 3 & 3 & 3 & 3 & 3 & 33 \\
\hline Bade et al., $2014^{30}$ & 3 & 3 & 3 & 3 & 3 & NA & 3 & 3 & 3 & 3 & 3 & 3 & 33 \\
\hline Bala et al., $2017^{31}$ & 3 & 3 & 3 & 3 & 3 & NA & 3 & 3 & 3 & 3 & 3 & 3 & 33 \\
\hline Banerjee et al., $2018^{32}$ & 3 & 3 & 3 & 3 & 3 & NA & 3 & 3 & 3 & 3 & 3 & 3 & 33 \\
\hline Bhandari et al., $2017^{33}$ & 3 & 3 & 3 & 3 & 3 & NA & 3 & 3 & 3 & 3 & 3 & 3 & 33 \\
\hline Begum et al., $2017^{34}$ & 3 & 3 & 3 & 3 & 3 & NA & 3 & 3 & 3 & 3 & 3 & 3 & 33 \\
\hline Chaudhary et al., $2018^{35}$ & 3 & 3 & 3 & 3 & 3 & NA & 3 & 3 & 3 & 3 & 3 & 3 & 33 \\
\hline Chavda et al., $2017^{36}$ & 3 & 3 & 3 & 3 & 3 & NA & 3 & 3 & 3 & 3 & 3 & 3 & 33 \\
\hline Chhetri et al., $2011^{37}$ & 3 & 3 & 3 & 3 & 3 & NA & 3 & 3 & 3 & 3 & 3 & 3 & 33 \\
\hline Das et al., $2018^{38}$ & 3 & 3 & 3 & 3 & 3 & NA & 3 & 3 & 3 & 3 & 3 & 3 & 33 \\
\hline Desai et al., $2017^{39}$ & 3 & 3 & 3 & 3 & 3 & NA & 3 & 3 & 3 & 3 & 3 & 3 & 33 \\
\hline Dhakal et al., $2018^{40}$ & 3 & 3 & 3 & 3 & 3 & NA & 3 & 3 & 3 & 3 & 3 & 3 & 33 \\
\hline Dhodapkar et al., $2015^{41}$ & 3 & 3 & 3 & 3 & 3 & NA & 3 & 3 & 3 & 3 & 3 & 3 & 33 \\
\hline Ehtisham et al., $2014^{42}$ & 3 & 3 & 3 & 3 & 3 & NA & 3 & 3 & 3 & 3 & 3 & 3 & 33 \\
\hline Goonewardene et al., $2012^{43}$ & 3 & 3 & 3 & 3 & 3 & NA & 3 & 3 & 3 & 3 & 3 & 3 & 33 \\
\hline Gupta et al., $2017^{44}$ & 3 & 3 & 3 & 3 & 3 & NA & 3 & 3 & 3 & 3 & 3 & 3 & 33 \\
\hline Hafeez et al., $2014^{45}$ & 3 & 3 & 3 & 3 & 3 & NA & 3 & 3 & 3 & 3 & 3 & 3 & 33 \\
\hline Gurung et al., $2016^{46}$ & 3 & 3 & 3 & 3 & 3 & NA & 3 & 3 & 3 & 3 & 3 & 3 & 33 \\
\hline Ishaq et al., $2017^{47}$ & 3 & 3 & 3 & 3 & 3 & NA & 3 & 3 & 3 & 3 & 3 & 3 & 33 \\
\hline Jain et al., $2018^{49}$ & 3 & 3 & 3 & 3 & 3 & NA & 3 & 3 & 3 & 3 & 3 & 3 & 33 \\
\hline Jawa et al., $2016^{49}$ & 3 & 3 & 3 & 3 & 3 & NA & 3 & 3 & 3 & 3 & 3 & 3 & 33 \\
\hline Karim et al., $2011^{50}$ & 3 & 3 & 3 & 3 & 3 & NA & 3 & 3 & 3 & 3 & 3 & 3 & 33 \\
\hline Dayanada et al., $2015^{51}$ & 3 & 3 & 3 & 3 & 3 & NA & 3 & 3 & 3 & 3 & 3 & 3 & 33 \\
\hline Malla et al., $2018^{52}$ & 3 & 3 & 3 & 3 & 3 & NA & 3 & 3 & 3 & 3 & 3 & 3 & 33 \\
\hline Manjulatha et al., $2015^{53}$ & 3 & 3 & 3 & 3 & 3 & NA & 3 & 3 & 3 & 3 & 3 & 3 & 33 \\
\hline Mehta et al., $2018^{54}$ & 3 & 3 & 3 & 3 & 3 & NA & 3 & 3 & 3 & 3 & 3 & 3 & 33 \\
\hline Mittal et al., $2014^{55}$ & 3 & 3 & 3 & 3 & 3 & NA & 3 & 3 & 3 & 3 & 3 & 3 & 33 \\
\hline Nazneen et al., $2011^{56}$ & 3 & 3 & 3 & 3 & 3 & NA & 3 & 3 & 3 & 3 & 3 & 3 & 33 \\
\hline Naeem et al., $2015^{57}$ & 3 & 3 & 3 & 3 & 3 & NA & 3 & 3 & 3 & 3 & 3 & 3 & 33 \\
\hline Nikhil et al., $2015^{58}$ & 3 & 3 & 3 & 3 & 3 & NA & 3 & 3 & 3 & 3 & 3 & 3 & 33 \\
\hline Pradhan et al., $2014^{59}$ & 3 & 3 & 3 & 3 & 3 & NA & 3 & 3 & 3 & 3 & 3 & 3 & 33 \\
\hline Pradhan et al., $2014^{60}$ & 3 & 3 & 3 & 3 & 3 & NA & 3 & 3 & 3 & 3 & 3 & 3 & 33 \\
\hline Preetkamal et al., $2017^{61}$ & 3 & 3 & 3 & 3 & 3 & NA & 3 & 3 & 3 & 3 & 3 & 3 & 33 \\
\hline Samdal et al., $2016^{62}$ & 3 & 3 & 3 & 3 & 3 & NA & 3 & 3 & 3 & 3 & 3 & 3 & 33 \\
\hline Santhanalakshmi et al., $2016^{63}$ & 3 & 3 & 3 & 3 & 3 & NA & 3 & 3 & 3 & 3 & 3 & 3 & 33 \\
\hline Sarma et al., $2016^{64}$ & 3 & 3 & 3 & 3 & 3 & NA & 3 & 3 & 3 & 3 & 3 & 3 & 33 \\
\hline Singh et al., $2018^{65}$ & 3 & 3 & 3 & 3 & 3 & NA & 3 & 3 & 3 & 3 & 3 & 3 & 33 \\
\hline Subedi et al., $2018^{66}$ & 3 & 3 & 3 & 3 & 3 & NA & 3 & 3 & 3 & 3 & 3 & 3 & 33 \\
\hline Tahir et al., $2018^{67}$ & 3 & 3 & 3 & 3 & 3 & NA & 3 & 3 & 3 & 3 & 3 & 3 & 33 \\
\hline
\end{tabular}




\begin{tabular}{|c|c|c|c|c|c|c|c|c|c|c|c|c|c|}
\hline Studies & Q1 & Q2 & Q3 & Q4 & Q5 & Q6 & Q7 & Q8 & Q9 & Q10 & Q11 & Q12 & Total score \\
\hline Jabeen et al., $2013^{68}$ & 3 & 3 & 3 & 3 & 3 & NA & 3 & 3 & 3 & 3 & 3 & 3 & 33 \\
\hline Saxena et al., $2016^{69}$ & 3 & 3 & 3 & 3 & 3 & NA & 3 & 3 & 3 & 3 & 3 & 3 & 33 \\
\hline Aminu et al., $2014^{70}$ & 3 & 3 & 3 & 3 & 3 & NA & 3 & 3 & 3 & 3 & 3 & 3 & 33 \\
\hline Rijal et al., $2014^{71}$ & 3 & 3 & 3 & 3 & 3 & NA & 3 & 3 & 3 & 3 & 3 & 3 & 33 \\
\hline Baig et al., $2016^{72}$ & 3 & 3 & 3 & 3 & 3 & NA & 3 & 3 & 3 & 3 & 3 & 3 & 33 \\
\hline Kim et al., $2012^{74}$ & 3 & 3 & 3 & 3 & 3 & NA & 3 & 3 & 3 & 3 & 3 & 3 & 33 \\
\hline Rafique et al., $2012^{75}$ & 3 & 3 & 3 & 3 & 3 & NA & 3 & 3 & 3 & 3 & 3 & 3 & 33 \\
\hline Prasad et al., $2017^{76}$ & 3 & 3 & 3 & 3 & 3 & NA & 3 & 3 & 3 & 3 & 3 & 3 & 33 \\
\hline Islam et al., $2015^{77}$ & 3 & 3 & 3 & 3 & 3 & NA & 3 & 3 & 3 & 3 & 3 & 3 & 33 \\
\hline Amatya et al., $2014^{78}$ & 3 & 3 & 3 & 3 & 3 & NA & 3 & 3 & 3 & 3 & 3 & 3 & 33 \\
\hline Patil et al., $2017^{79}$ & 3 & 3 & 3 & 3 & 3 & NA & 3 & 3 & 3 & 3 & 3 & 3 & 33 \\
\hline Subhashini et al., $2015^{80}$ & 3 & 3 & 3 & 3 & 3 & NA & 3 & 3 & 3 & 3 & 3 & 3 & 33 \\
\hline Sultana et al., $2017^{81}$ & 3 & 3 & 3 & 3 & 3 & NA & 3 & 3 & 3 & 3 & 3 & 3 & 33 \\
\hline Birla et al., $2016^{82}$ & 3 & 3 & 3 & 3 & 3 & NA & 3 & 3 & 3 & 3 & 3 & 3 & 33 \\
\hline Jayanthi et al., $2017^{85}$ & 3 & 3 & 3 & 3 & 3 & NA & 3 & 3 & 3 & 3 & 3 & 3 & 33 \\
\hline Latif et al.,201786 & 3 & 3 & 3 & 3 & 3 & NA & 3 & 3 & 3 & 3 & 3 & 3 & 33 \\
\hline Paudyal et al., $2014^{84}$ & 3 & 3 & 3 & 3 & 3 & NA & 3 & 3 & 3 & 3 & 3 & 3 & 33 \\
\hline Goonewardene et al., $2016^{86}$ & 3 & 3 & 3 & 3 & 3 & NA & 3 & 3 & 3 & 3 & 3 & 3 & 33 \\
\hline Ajeet et al., $2013^{84}$ & 3 & 3 & 3 & 3 & 3 & NA & 3 & 3 & 3 & 3 & 3 & 3 & 33 \\
\hline Khanal et al., $2016^{87}$ & 3 & 3 & 3 & 3 & 3 & NA & 3 & 3 & 3 & 3 & 3 & 3 & 33 \\
\hline Karkee et al., $2014^{94}$ & 3 & 3 & 3 & 3 & 3 & NA & 3 & 3 & 3 & 3 & 3 & 3 & 33 \\
\hline Yadav et al., $2016^{88}$ & 3 & 3 & 3 & 3 & 3 & NA & 3 & 3 & 3 & 3 & 3 & 3 & 33 \\
\hline Neuman et al., $2014^{89}$ & 3 & 3 & 3 & 3 & 3 & NA & 3 & 3 & 3 & 3 & 3 & 3 & 33 \\
\hline Ali et al., $2018^{91}$ & 3 & 3 & 3 & 3 & 3 & NA & 3 & 3 & 3 & 3 & 3 & 3 & 33 \\
\hline Hasan et al., $2015^{92}$ & 3 & 3 & 3 & 3 & 3 & NA & 3 & 3 & 3 & 3 & 3 & 3 & 33 \\
\hline Rahman et al., $2014^{93}$ & 3 & 3 & 3 & 3 & 3 & NA & 3 & 3 & 3 & 3 & 3 & 3 & 33 \\
\hline
\end{tabular}

\begin{tabular}{|c|c|c|c|c|c|c|c|c|c|c|c|c|c|}
\hline Studies & Q1 & Q2 & Q3 & Q4 & Q5 & Q6 & Q7 & Q8 & Q9 & Q10 & Q11 & Q12 & Total score \\
\hline Sultana et al., 2017 & 2 & 1 & 1 & 1 & 1 & NA & 1 & 2 & 2 & 2 & 2 & 2 & 17 \\
\hline Gurung et al., 2017 & 2 & 2 & 1 & 1 & 1 & NA & 1 & 2 & 2 & 2 & 2 & 2 & 18 \\
\hline Suwal et al., 2013 & 2 & 2 & 1 & 1 & 2 & NA & 1 & 2 & 2 & 2 & 2 & 2 & 19 \\
\hline
\end{tabular}




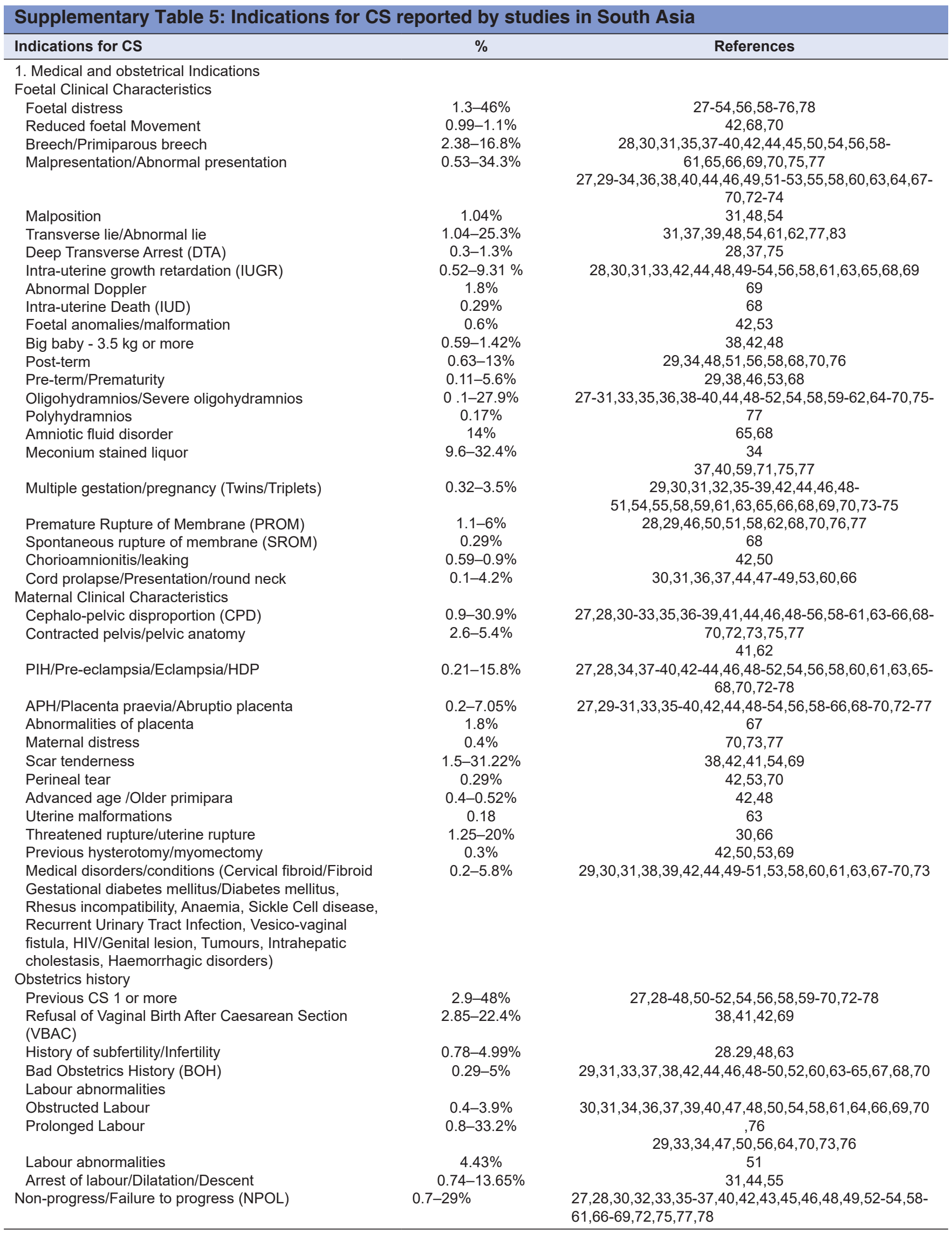




\begin{tabular}{|c|c|c|}
\hline \multicolumn{3}{|c|}{ Supplementary Table 5: (Continued) } \\
\hline Indications for CS & $\%$ & References \\
\hline Failed induction & $0.40-15.7 \%$ & $\begin{array}{c}27,28,30-33,36,37,39,40,43,44,46-53,56,58-60,63- \\
66,68-71,75,77,78\end{array}$ \\
\hline Dystocia & $13.8 \%$ & 71 \\
\hline Failed vacuum/instrumental & $2.3 \%$ & 40 \\
\hline Poor Bishop & $1.05 \%$ & 68 \\
\hline Cervical dystocia & $0.2-7.7 \%$ & $29,56,63$ \\
\hline Unfavourable cervix & $0.9-6.9 \%$ & $27,41,70$ \\
\hline Others & $0.5-36.2 \%$ & $34,35,37,39,40,47,52,60,75,76$ \\
\hline \multicolumn{3}{|l|}{ 2. Non-medical indications 27} \\
\hline Maternal choice/Request/Demand & $0.1-3.97 \%$ & $29,37,42,56,66,67$ \\
\hline Labour pain & $0.2 \%$ & 70 \\
\hline Previous traumatic birth experience & $2.2 \%$ & 62 \\
\hline Precious pregnancy & $0.47-3.96 \%$ & $36,42,50,63,68$ \\
\hline No indication recorded/Unspecified & $0.6-8.9 \%$ & $68.70,73,76$ \\
\hline
\end{tabular}




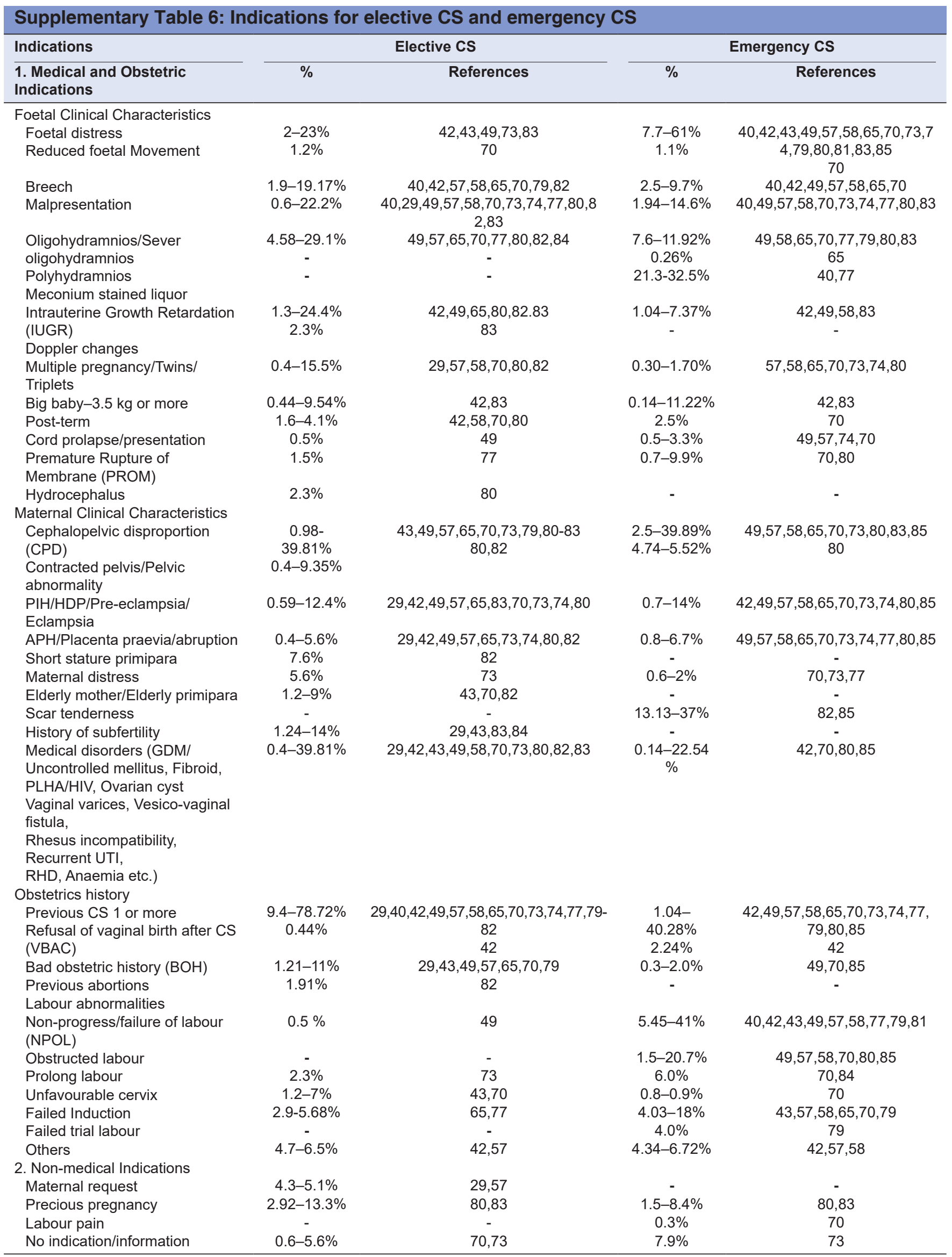




\begin{tabular}{|c|c|c|c|c|}
\hline \multirow{2}{*}{$\begin{array}{l}\text { Indications } \\
\text { 1. Medical and Obstetric Indications }\end{array}$} & \multicolumn{2}{|c|}{ Primary CS } & \multicolumn{2}{|c|}{ Repeat CS } \\
\hline & $\%$ & References & $\%$ & References \\
\hline \multicolumn{5}{|l|}{ Foetal Clinical Characteristics } \\
\hline Foetal distress & $5.58-60.8 \%$ & $50,55,67,70,89,83,86$ & $5.96-32.65 \%$ & $44,48,50,55,80,83$ \\
\hline Non-reassuring foetal status & $8.2 \%$ & 84 & - & - \\
\hline Foetal hypoxia & $3.16 \%$ & 86 & - & - \\
\hline Absent end diastolic flow & $0.4 \%$ & 84 & - & - \\
\hline Malpresentation, & $3.29-34.3 \%$ & $55,67,80,83,84$ & $2.94-10 \%$ & $44,48,50$ \\
\hline Breech & $15.8-19.17$ & $50,70,86$ & $0.64-16.1 \%$ & $44,48,55,80,83$ \\
\hline Deep transverse arrest (DTA) & $0.7-1.47 \%$ & 84,86 & - & - \\
\hline Transverse lie & $1.26 \%$ & 86 & - & - \\
\hline Brow presentation & $0.84 \%$ & 86 & - & - \\
\hline Face presentation & $0.21 \%$ & 86 & - & - \\
\hline Multiple gestation/pregnancy (Twins/Triplets) & $0.4-15.5 \%$ & $50,55,80$ & $0.28-4.2 \%$ & $44,48,50,55,80$ \\
\hline Severe Oligohydramnios/Oligohydramnios & $3.4-29.1 \%$ & $80,83,84,86$ & $4.58-8.4 \%$ & $44,48,80,83$ \\
\hline Meconium stain liquor & $22 \%$ & 84 & - & - \\
\hline Intrauterine Growth Retardation (IUGR) & $3.3-6.31 \%$ & $80,83,86$ & $1.68-7.70 \%$ & $44,48,80,83$ \\
\hline Premature Rupture of Membrane (PROM) & $2.10 \%$ & 70,86 & $0.7-5.6 \%$ & 80 \\
\hline Cord prolapse /cord round neck & $0.63 \%$ & 86 & $1.4 \%$ & 80 \\
\hline Big baby- $3.5 \mathrm{~kg}$ or more & $5.58-11.22 \%$ & 83 & $1.68 \%$ & $44,48,83$ \\
\hline Prematurity & - & - & $0.59-0.84 \%$ & 44,48 \\
\hline Post-term & - & - & $0.7-1.6 \%$ & 80 \\
\hline Hydrocephalus & - & - & $2.3 \%$ & 80 \\
\hline \multicolumn{5}{|l|}{ Maternal Clinical Characteristics } \\
\hline Cephalopelvic disproportion (CPD) & $0.9-20 \%$ & $50,55,70,80,83,84,86$ & $1.63-30.25 \%$ & $44,48,50,55,80,83$ \\
\hline Pelvic abnormality/Contracted pelvis & $0.4-8.4 \%$ & 84,85 & $5.52-9.35 \%$ & 80 \\
\hline APH/Placenta previa/Abruptio placenta & $0.4-5.6 \%$ & $50,80,84,86$ & $0.59-5.8 \%$ & $44,48,50,80$ \\
\hline Abnormalities of placenta & $2.3 \%$ & 67 & & \\
\hline Uteroplacental insufficiency (UPI) & $1.68 \%$ & 86 & & \\
\hline $\mathrm{PIH} /$ Severe pre-eclampsia/eclampsia & $2.3-11.9 \%$ & $50,67,80,84,86$ & $0.7-10.08 \%$ & $44,48,50,80$ \\
\hline Scar tenderness & & - & $0.72-21 \%$ & $44,48,55,80,83$ \\
\hline $\begin{array}{l}\text { Medical disorders (RHD, Cervical fibroid, GDM, } \\
\text { Haemorrhagic disorders) }\end{array}$ & $0.4-5.4 \%$ & 67,84 & $0.42-2.3 \%$ & $44,48,80,83$ \\
\hline \multicolumn{5}{|l|}{ Obstetric history } \\
\hline Bad obstetrics history $(\mathrm{BOH})$ & $4.0 \%$ & 67 & $0.29-2.52 \%$ & 44,48 \\
\hline Previous CS 1 or more & - & - & $1.31-48.5 \%$ & $44,48,50,55,70,83$ \\
\hline Refusal of Vaginal Birth & - & - & $0.23-0.23$ & 44,55 \\
\hline \multicolumn{5}{|l|}{ Labour abnormalities } \\
\hline Obstructed labour & $1.3-8.2 \%$ & $50,70,80,84,86$ & $7.5 \%$ & 50 \\
\hline Prolonged Labour & $9.5 \%$ & 50 & $0.8 \%$ & 50 \\
\hline Non/fail progression of labour (NPOL) & $12.6-36.6 \%$ & $67,70,80,84,86$ & - & - \\
\hline Cervical dystocia & $2.42 \%$ & 55,84 & _- & - \\
\hline Arrest of labour/Dilatation/Descent & $0.2-1.68 \%$ & 55 & $0.10-0.75 \%$ & 55 \\
\hline Fail induction & $4.2-12.7 \%$ & $70,80,84,86$ & - & - \\
\hline Others & $0.9-18.2 \%$ & 50,67 & $0.10-0.75 \%$ & 55 \\
\hline \multicolumn{5}{|l|}{ 2. Non-medical indications } \\
\hline Maternal request & $0.2 \%$ & 67,82 & - & - \\
\hline Precious Pregnancy & $1.5-13.3 \%$ & $80,83,84,86$ & $2.53-9.7 \%$ & 80,83 \\
\hline
\end{tabular}




\begin{tabular}{|c|c|c|c|c|}
\hline \multirow{2}{*}{$\begin{array}{l}\text { Indications of CS } \\
\text { 1. Medical \& Obstetric Indications }\end{array}$} & \multicolumn{2}{|c|}{ Primigravida } & \multicolumn{2}{|c|}{ Multigravida } \\
\hline & $\%$ & References & $\%$ & References \\
\hline \multicolumn{5}{|l|}{ Foetal Clinical Characteristics } \\
\hline Foetal distress & $8.3-53 \%$ & $43,58,62,70,86,87$ & $11.4-61 \%$ & $43,58,62,86$ \\
\hline Foetal hypoxia & $3.16 \%$ & 86 & $2.18 \%$ & 86 \\
\hline Malpresentation & $1-14 \%$ & 58,87 & $7 \%$ & 58 \\
\hline Breech & $12.63 \%$ & $58,82,86$ & $6-10.18 \%$ & 58,86 \\
\hline Brow presentation & $0.84 \%$ & 86 & $0.73 \%$ & 86 \\
\hline Face presentation & $0.21 \%$ & 86 & $1.09 \%$ & 86 \\
\hline Abnormal foetal lie/Transverse lie & $1.26-27.8 \%$ & $62,82,86$ & $5.45-22.9 \%$ & 62,86 \\
\hline Deep Transverse Arrest (DTA) & $1.47 \%$ & 86 & $0.73 \%$ & 86 \\
\hline Oligohydramnios/Severe oligohydramnios & $1.9-29.1 \%$ & $58,62,82,86$ & $1-7.64 \%$ & $58,62,86$ \\
\hline Chorioamnionitis & $2.1 \%$ & 86 & - & - \\
\hline Premature Rupture of Membrane (PROM) & $2.10 \%$ & 86 & $1.1-4.73 \%$ & 62,86 \\
\hline Intra-uterine Growth Retardation (IUGR) & $3.3-6.31 \%$ & $58,82,86$ & $1-4.73 \%$ & 58,86 \\
\hline Doppler changes & $2.3 \%$ & 82 & - & - \\
\hline Multiple pregnancy (Twins /Triplets) & $0.4-2.3 \%$ & 82 & - & - \\
\hline Post-term & $19 \%$ & 70 & - & - \\
\hline Cord prolapse/Cord presentation & $0.63 \%$ & 86 & $0.36-1.45 \%$ & 86 \\
\hline Vasa previa & - & - & $0.36 \%$ & 86 \\
\hline \multicolumn{5}{|l|}{ Maternal Clinical Characteristics } \\
\hline Cephalo-pelvic Disproportion (CPD) & $7 \%-23 \%$ & $43,58,70,82,86$ & $3-13.82 \%$ & 58,86 \\
\hline Contracted pelvis/Pelvic anatomy & $0.4-11.1 \%$ & 62,82 & $14.3 \%$ & 62 \\
\hline PIHVEclampsia/HDP & $0.21-11.9 \%$ & $82,86,87$ & $9.09 \%$ & 85 \\
\hline Elderly primipara /Elderly mother & $2.3-9 \%$ & 43,82 & - & - \\
\hline Short stature primipara & $7.6 \%$ & 82 & - & - \\
\hline Placenta previa/Placenta abruption & $0.4-1.9 \%$ & $62,82,86$ & $1.1-12.73 \%$ & 62,86 \\
\hline Uteroplacental insufficiency (UPI) & $1.68 \%$ & 85 & $2.54 \%$ & 86 \\
\hline Medical disorders (GDM, Fibroid in uterus, & $0.4-5.4 \%$ & 82 & - & - \\
\hline Vaginal varices) & - & - & $22 \%$ & 43 \\
\hline \multicolumn{5}{|l|}{ Obstetric history } \\
\hline Primary Subfertility/Long marital life & $2.3-14 \%$ & 43,82 & - & - \\
\hline Previous abortions/Bad obstetric history $(\mathrm{BOH})$ & $1.91 \%$ & 82 & $11-11.27 \%$ & 43 \\
\hline Previous CS & - & - & $20 \%$ & 62 \\
\hline \multicolumn{5}{|l|}{ Labour abnormalities } \\
\hline Obstructed labour & $0.47-8.2 \%$ & $58,85,87$ & $2-6.54 \%$ & 58,86 \\
\hline Prolonged labour & $33.3 \%$ & 62 & $17.1 \%$ & 63 \\
\hline Non/Failed progress of Labour (NPOL) & $10.7-41 \%$ & $43,86,87$ & $8.73-15 \%$ & 43,58 \\
\hline Failed induction & $6.10-33.3 \%$ & $43,86,87$ & $3.64-39 \%$ & $43,63,86$ \\
\hline Unfavourable cervix & $7 \%$ & 43 & - & - \\
\hline \multicolumn{5}{|l|}{ 2. Non-medical Indications } \\
\hline Patients' request & $2.87 \%$ & 87 & - & - \\
\hline Precious pregnancy & $1.67-1.68 \%$ & 89,87 & - & - \\
\hline Previous traumatic birth experience & - & - & $5.7 \%$ & 62 \\
\hline
\end{tabular}

